\title{
Philippines: Financial System Stability Assessment Update
}

This Financial System Stability Assessment Update on Philippines was prepared as background documentation for the periodic IMF consultation with the member country. It is based on the information available at the time it was completed on January 11, 2010. The views expressed in this document are those of the staff team and do not necessarily reflect the views of the government of Philippines or the Executive Board of the IMF.

The policy of publication of staff reports and other documents by the IMF allows for the deletion of market-sensitive information.

Copies of this report are available to the public from

International Monetary Fund $\bullet$ Publication Services

700 19th Street, N.W. • Washington, D.C. 20431

Telephone: (202) 623-7430 • Telefax: (202) 623-7201

E-mail: publications@imf.org • Internet: http://www.imf.org

\section{International Monetary Fund Washington, D.C.}




\title{
INTERNATIONAL MONETARY FUND
}

\section{PHILIPPINES}

\section{Financial System Stability Assessment_-Update}

\author{
Prepared by the Monetary and Capital Markets and Asia and Pacific Departments \\ Approved by José Viñals and Anoop Singh
}

January 11,2010

This Financial Sector Stability Assessment (FSSA) is based on the work of a joint IMF/World Bank Financial Sector Assessment Program (FSAP) Update mission to Manila from November 4-17, 2009. The initial FSAP took place in 2002. The Update team comprised Dimitri G. Demekas (co-head of mission, IMF), Wang Jun (cohead of mission, World Bank), Leif Eskesen, Hideyuki Hotta, Joji Ide, Pamela Madrid, Fabiana Melo, and Liliana Schumacher (all IMF); and Loic Chiquier, Jonathan Katz, Rekha Reddy, Tom Rose, and Craig Thorburn (all World Bank). The main findings were:

- The banking sector has been strengthened considerably since the Asian crisis of the late 1990s and today appears generally resilient to a broad range of macroeconomic risks. The impact of the ongoing global crisis has thus far been milder than originally feared and the macroeconomic outlook is improving, although risks remain elevated in the near term.

- Considerable progress has been made toward implementing the recommendations of the initial FSAP, particularly in banking supervision, but also in strengthening the bank resolution framework and nonbank supervision.

- $\quad$ Further strengthening of supervisory powers and practices is needed to bring supervision and bank safety nets up to best international standards and practices. In particular, it is critical to ensure adequate legal protection for supervisors and eliminate bank secrecy with respect to supervisory duties.

- Development of the nonbank financial sectors would help growth and risk diversification. Capital markets and the insurance sector would benefit from harmonizing various taxes and lowering the regulatory burden on some products and services. In the housing finance sector the multitude of government interventions and institutions need to be rationalized.

The main author of this report is Pamela Madrid, with contributions from the members of the team.

FSAP assessments are designed to assess the stability of the financial system as a whole and not that of individual institutions. They have been developed to help countries identify and remedy weaknesses in their financial sector structure, thereby enhancing their resilience to macroeconomic shocks and cross-border contagion. FSAP assessments do not cover risks that are specific to individual institutions such as asset quality, operational or legal risks, or fraud. 


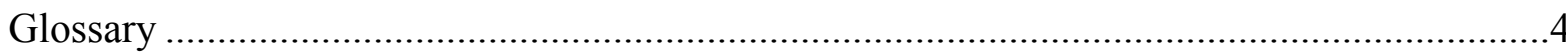

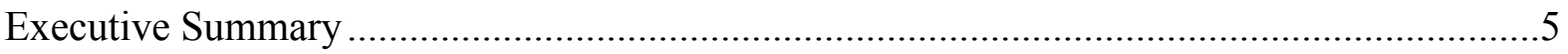

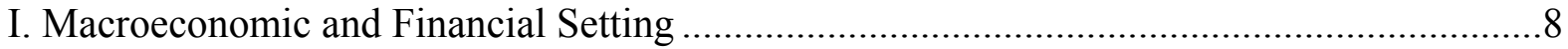

A. Structure of the Financial Sector...........................................................................

B. Recent Macroeconomic Trends and Outlook....................................................10

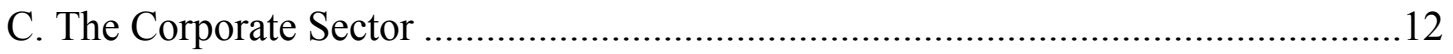

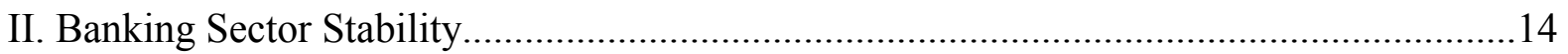

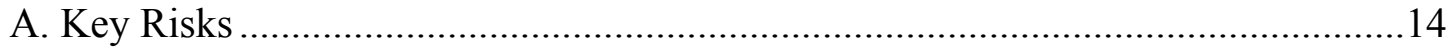

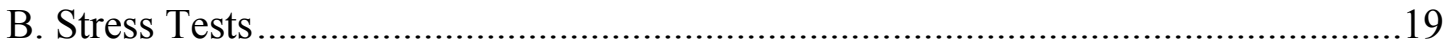

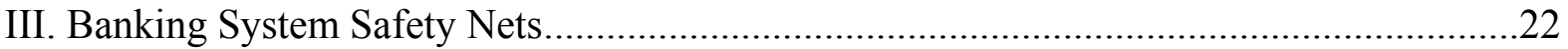

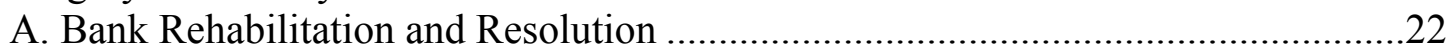

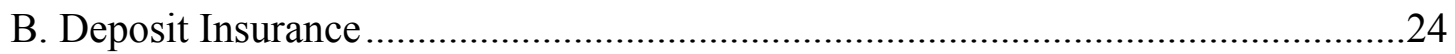

C. Liquidity and Risk Capital Assistance ..................................................................25

D. Crisis Preparedness and Crisis Management Arrangements.....................................26

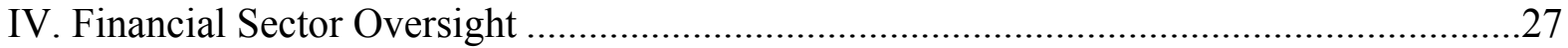

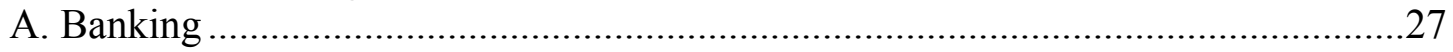

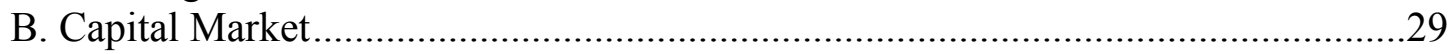

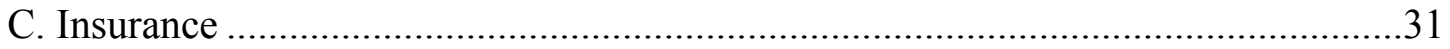

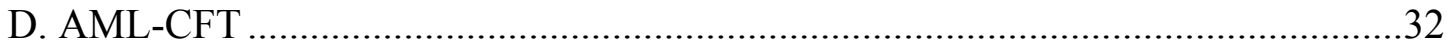

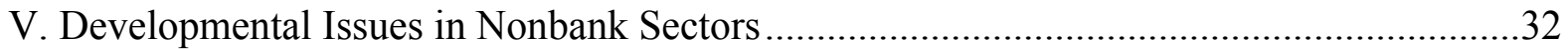

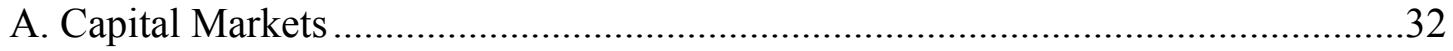

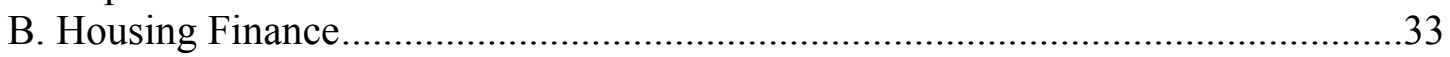

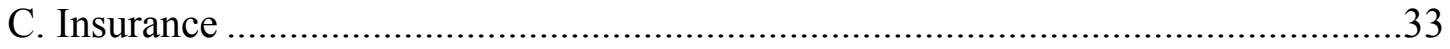

Tables

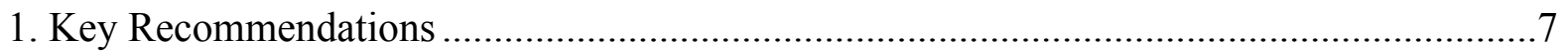

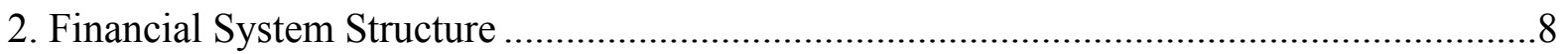

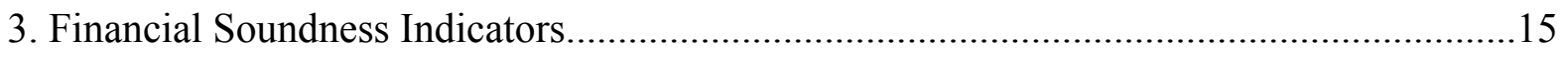

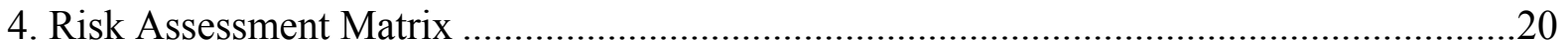

Figures

1. Credit-to-GDP

2. Macroeconomic and Financial Market Developments .......................................................11

3. Corporate Sector Income and Balance Sheet Indicators....................................................13

4. Corporate Sector Expected Default Probabilities ...............................................................13

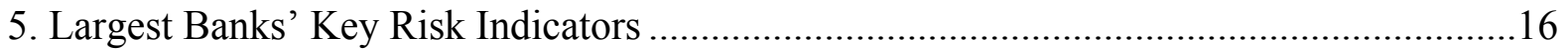

6. Thrift, Rural, and Cooperative Banks' Key Risk Indicators................................................17 


\section{Appendices}

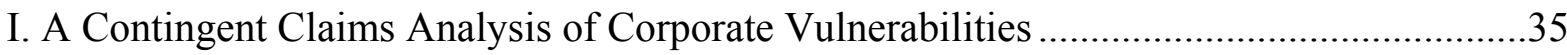

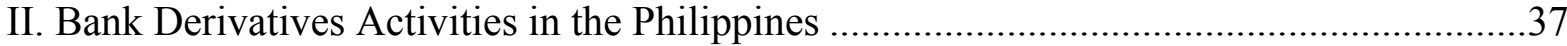

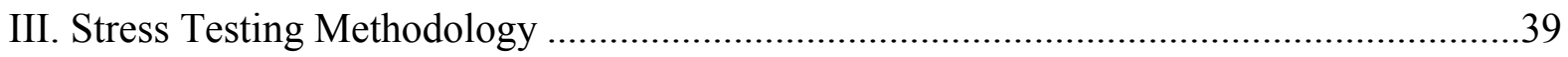




\section{GLOSSARY}

$\begin{array}{ll}\text { AML } & \text { Anti-money laundering } \\ \text { BCP } & \text { Basle Core Principles for Effective Banking Supervision } \\ \text { BSP } & \text { Bangko Sentral ng Pilipinas - Central Bank of the Philippines } \\ \text { CAR } & \text { Capital adequacy ratio } \\ \text { DOSRI } & \text { Directors, officers, stockholders and related interests } \\ \text { ELA } & \text { Emergency liquidity assistance } \\ \text { FSAP } & \text { Financial Sector Assessment Program } \\ \text { FSF } & \text { Financial Sector Forum } \\ \text { FSR } & \text { Financial Stability Report } \\ \text { GBL } & \text { General banking law } \\ \text { GSIS } & \text { Government Services Insurance System } \\ \text { IAIS } & \text { International Association of Insurance Supervisors } \\ \text { IAS } & \text { International Accounting Standards } \\ \text { IFRS } & \text { International Financial Reporting Standards } \\ \text { IOSCO } & \text { International Organization of Securities Commissions } \\ \text { MBA } & \text { Mutual benefit association } \\ \text { MOU } & \text { Memorandum of Understanding } \\ \text { NCBA } & \text { New Central Banking Act } \\ \text { NPA } & \text { Nonperforming asset } \\ \text { NPL } & \text { Nonperforming loan } \\ \text { PCA } & \text { Prompt corrective action } \\ \text { PDEX } & \text { Philippine Dealing and Exchange } \\ \text { PDIC } & \text { Philippine Deposit Insurance Corporation } \\ \text { PSE } & \text { Philippine Stock Exchange } \\ \text { RBC } & \text { Risk-based capital } \\ \text { REIT } & \text { Real estate investment trust } \\ \text { ROPA } & \text { Real and other property acquired } \\ \text { SEC } & \text { Securities and Exchange Commission } \\ \text { SPV } & \text { Special purpose vehicle } \\ \text { SRO } & \text { Self-regulatory organization } \\ & \end{array}$




\section{EXECUTIVE SUMMARY}

The banking sector - the core of the Philippine financial system-appears resilient. Banks dominate the Philippine financial system, with about two-thirds of total system assets. Since the Asian crisis of the late 1990s, a benign economic environment, bank restructuring and consolidation, and the shedding of nonperforming assets have all helped improve bank soundness. Partly as a result, the impact of the current global crisis has thus far been milder than initially expected. Although macroeconomic risks remain elevated, the banking system is well-capitalized and liquid, and asset quality is generally high. Stress tests suggest that the ten largest banks are resilient to a wide range of credit, market, and liquidity risks. However, the asset quality of thrifts, cooperatives, and rural banks is weaker and provisions are low.

\section{Considerable progress has been made in implementing the recommendations of the} 2002 FSAP assessment, especially in banking. Steps to facilitate the disposal of nonperforming bank assets from the Asian crisis were accompanied by a significant strengthening of the regulatory framework and the BSP's supervisory capabilities. Also, the debt market continued to develop, bank secrecy was relaxed partially, supervisory coordination was improved, and new AML legislation was passed. However, progress in other areas was patchy: capital market and insurance supervision remain largely complianceoriented, the legal framework and supervisory agencies in these sectors need further strengthening, there is a plethora of overlapping and distortionary government policies in the financial sector, and legal protection of supervisors, though improved, remains weak.

\section{Nonbank financial sectors remain weak and underdeveloped:}

- $\quad$ Equity market listings have been nearly stagnant and the private bond market remains small relative to regional peers. The insurance sector is also relatively small and has even contracted in real terms since 2002. Complex and heterogeneous taxation and overly restrictive rules on product distribution stymie development of these sectors.

- $\quad$ The presence of several government agencies with overlapping mandates benefiting from government subsidies distorts housing finance. Many state-owned housing finance entities (although these are not systemically important) have very weak loan portfolios, are poorly managed, and represent fiscal contingent liabilities.

Since the last FSAP, supervision has been strengthened considerably in banking and, to a somewhat lesser extent, in capital markets and insurance; further progress in all three areas, however, depends critically on passing pending legislation. Progress in banking has been notable, in particular the adoption of Basel II and IFRS and strengthening of risk-based supervision, but progress in other areas has been uneven.

- $\quad$ Key priorities in banking supervision now include passing the proposed amendments to the New Central Banking Act (NCBA). Further reforms may be needed to provide 
greater discretion to the BSP to require additional capital and impose other limits on banks; broaden the definition of connected counterparties; and expand and harmonize the definitions of single borrower limits and large exposures.

- Capital market supervision should focus on enhancing on-site examinations, enforcement, and the use of self-regulatory organizations. Making progress here requires rationalizing the mandate of the SEC and providing it with adequate resources.

- Strengthening insurance supervision requires passing the pending amendments to the Insurance Code and supplementing them with provisions that provide the Commission with a broader set of discretionary intervention tools.

- In all three areas, it is imperative to roll back bank secrecy provisions that hamper PDIC and supervisors' access to individual deposit and investment information, and to provide them with adequate legal protection, in line with Basel Core Principles.

The current global financial crisis underscores the importance of strong financial safety nets. The enhanced Prompt Corrective Action framework of 2006 was a big step in this direction, and the proposed amendments to the NCBA will strengthen further resolution powers. But the balance between shareholder rights and efficient resolution should shift more in favor of the latter, notably by empowering the authorities to take full control of a bank once capital adequacy falls below a critical threshold. The resolution framework should also allow for a bridge bank resolution mechanism. For the PDIC to play its role effectively, it should be given access to asset and individual deposit information at an early stage when the viability of a bank is in question. Conditions for emergency liquidity assistance should be tightened. The creation of the Financial Sector Forum, comprising the BSP, PDIC, SEC, and Insurance Commission has considerably improved supervisory coordination, but this could be further strengthened by crisis contingency planning and by forging closer links with the Department of Finance, which would have a key role in the event of a systemic crisis.

\section{The development of nonbank sectors could enhance growth and risk diversification.}

- Housing finance policy, where there is a number of public agencies with overlapping mandates, many of which generate fiscal contingent liabilities, should be rationalized. They should be limited to their core mandates, their lending subjected to the same prudential rules as banks, and those that lack a clear business case should be closed.

- Capital and insurance market efficiency could be improved by inter alia harmonizing the tax treatment of financial products and services; reducing the time and expense of debt and mutual fund offerings; removing unnecessary restrictions on the sale of mutual funds; and facilitating the broader provision of insurance products. 
Table 1. Philippines FSAP Update-Key Recommendations

\begin{tabular}{|c|c|}
\hline Measure & Time frame ${ }^{1}$ \\
\hline \multicolumn{2}{|l|}{ Access to Finance } \\
\hline $\begin{array}{l}\text { Establish a credit bureau with positive and negative credit information that includes the whole } \\
\text { banking system and information about utility payments. }\end{array}$ & Short term \\
\hline Expand access points for mobile services provision. & Medium term \\
\hline \multicolumn{2}{|l|}{ Financial Sector Supervision-all sectors } \\
\hline $\begin{array}{l}\text { Expand legal protection for all supervisory staff (in line with proposed amendments to NCBA). } \\
\text { Allow full access to individual deposit and investment accounts to all financial sector } \\
\text { supervisory agencies (in line with proposed amendments to NCBA). }\end{array}$ & Short term \\
\hline \multicolumn{2}{|l|}{ Banking } \\
\hline Enact proposed amendments to NCBA. & Short term \\
\hline $\begin{array}{l}\text { Amend GBL and NCBA to give power to the BSP to set prudential rules without changing laws. } \\
\text { Amend NCBA to allow BSP to set additional required capital and other limits according to a } \\
\text { bank's risk profile. } \\
\text { Align the definition of connected counterparties in the GBL with the DOSRI regulation. } \\
\text { Amend the single borrower limit and the definition of large exposures so that both apply on a } \\
\text { solo and consolidated basis, include all on- and off-balance sheet exposures, and use the same } \\
\text { definition of capital. }\end{array}$ & Medium term \\
\hline \multicolumn{2}{|l|}{ Capital Markets } \\
\hline $\begin{array}{l}\text { Start onsite examinations for mutual funds and other SEC registered entities. } \\
\text { Amend SEC law to increase maximum penalties and have civil enforcement authority. } \\
\text { Enforce requirements on PSE ownership and create an autonomous and self-funded SRO for } \\
\text { both stock and debt markets, reporting to the SEC. } \\
\text { Comply with existing law for SEC staff salaries. }\end{array}$ & Short term \\
\hline Enact revised Investment Company Act. & Medium term \\
\hline \multicolumn{2}{|l|}{ Housing Finance } \\
\hline $\begin{array}{l}\text { Rationalize housing credit subsidy policy and role of public housing finance institutions. } \\
\text { Apply BSP rules on loan provisioning to public housing loans. }\end{array}$ & Short term \\
\hline Reduce foreclosure "redemption" period for individual borrowers. & Medium term \\
\hline \multicolumn{2}{|l|}{ Insurance } \\
\hline $\begin{array}{l}\text { Harmonize minimum capital requirement to eliminate the distinction based on domestic or } \\
\text { foreign ownership. } \\
\text { Adjust risk-based capital rule to reflect local risks, while increasing intervention thresholds and } \\
\text { rationalizing asset and investment requirements. } \\
\text { Strengthen and enhance minimum liability valuation rules for life insurance. } \\
\text { Start risk assessment, internal ratings, risk-focused interventions and targeted inspections. }\end{array}$ & Short term \\
\hline \multicolumn{2}{|l|}{ Safety Nets } \\
\hline $\begin{array}{l}\text { Amend PCA regulation to make it more progressive and timely. } \\
\text { Involve PDIC early on in dealing with PCA failure banks. } \\
\text { Allow conservator /receiver to take full control to restructure a bank without shareholder } \\
\text { approval once capital adequacy breaches a regulatory threshold. }\end{array}$ & Short term \\
\hline Amend law for a bridge bank resolution mechanism & Medium term \\
\hline
\end{tabular}

${ }^{1}$ Short term: $12-18$ months; medium term: $2-3$ years. 


\section{Macroeconomic and Financial Setting}

\section{A. Structure of the Financial Sector}

1. Banking dominates the Philippine financial system. After a significant consolidation following the Asian financial crisis of the 1990s, the Philippine banking system today (June 2009) comprises 804 deposit-taking institutions, including universal and commercial banks, as well as thrift, rural, and cooperative banks. Their assets total almost P6 trillion, some 75 percent of GDP or about two-thirds of total financial institutions' assets, an increase of almost 60 percent since 2003 (Table 2). Universal and commercial banksmostly domestic private banks - account for 88 percent of total banking assets, with the ten largest accounting for about two-thirds. ${ }^{2}$

Table 2. Philippines: Financial System Structure, 2003-2009

\begin{tabular}{|c|c|c|c|c|c|c|c|c|}
\hline \multirow{3}{*}{ Universal and commercial banks } & \multicolumn{4}{|c|}{ December 2003} & \multicolumn{4}{|c|}{ June 2009} \\
\hline & \multirow{2}{*}{$\begin{array}{c}\text { Number } \\
42\end{array}$} & \multirow{2}{*}{$\begin{array}{c}\text { Total Assets } \\
\text { (Peso bln.) } \\
3,297\end{array}$} & $\begin{array}{l}\text { Total Capital } \\
\text { (Peso bln.) }\end{array}$ & Employees & Number & $\begin{array}{c}\text { Total Assets } \\
\text { (Peso bln.) }\end{array}$ & $\begin{array}{l}\text { Total Capital } \\
\text { (Peso bln.) }\end{array}$ & Employees \\
\hline & & & 424 & 62,316 & 38 & 5,089 & 564 & 81,959 \\
\hline Private & 39 & 2,882 & 383 & 52,516 & 35 & 4,359 & 485 & 72,169 \\
\hline Domestic & 20 & 2,387 & 307 & 47,884 & 18 & 3,764 & 384 & 66,110 \\
\hline Foreign & 19 & 495 & 76 & 4,632 & 17 & 595 & 101 & 6,059 \\
\hline State-ow ned & 3 & 416 & 41 & 9,800 & 3 & 730 & 80 & 9,790 \\
\hline \multicolumn{9}{|l|}{ Other depository ins titutions } \\
\hline Thrift banks & 92 & 274 & 41 & 9,979 & 74 & 527 & 61 & 13,839 \\
\hline Rural banks & 721 & 84 & 13 & 15,270 & 648 & 143 & 24 & 24,709 \\
\hline Cooperative banks & 44 & 6 & 1 & 1,333 & 44 & 13 & 2 & 1,997 \\
\hline \multicolumn{9}{|l|}{ Other credit ins titutions } \\
\hline Building and loan associations & 4 & 550 & 435 & & 4 & Not available & Not available & Not available \\
\hline Savings and loans assocations & 85 & 61 & 54 & 10,478 & 75 & 80 & 64 & 10,699 \\
\hline \multicolumn{9}{|l|}{ Investment companies } \\
\hline Trust companies & 50 & 707 & Not applicable & 831 & 46 & 1,592 & Not applicable & 1,130 \\
\hline \multicolumn{9}{|l|}{ Financial auxiliaries } \\
\hline Foreign exchange houses & BSP starte & $\mathrm{d}$ regulating Fo & reign Exchange [ & ealers in 2005 & 1,627 & Not available & Not available & Not available \\
\hline \multicolumn{9}{|l|}{ Insurance and pensions } \\
\hline \multicolumn{9}{|l|}{ Insurance companies } \\
\hline Life & 32 & 208 & 9 & Not available & 28 & 411 & 10 & Not available \\
\hline Nonlife & 105 & 69 & 10 & Not available & 82 & 93 & 15 & Not available \\
\hline Mixed & 4 & ...1/ & $\ldots 1 /$ & Not available & 3 & $\ldots 1 /$ & $\ldots 1 /$ & Not available \\
\hline Total & 141 & 278 & 19 & 12,845 & 113 & 504 & 24 & 15,870 \\
\hline Pension funds & 4 & $6642 /$ & 579 & Not available & 4 & $11012 /$ & 1,002 & Not available \\
\hline
\end{tabular}

Source: BSP.

$1 /$ Life and non-life components reported separately under respective categories.

2/ Assets under management.

\footnotetext{
${ }^{2}$ Universal banks may also directly provide investment services and, indirectly, other financial services through allied companies.
} 


\section{Despite recently strong loan growth, deposit intermediation in the Philippines is} still relatively low. Bank credit to the private sector grew sluggishly for most of the last decade, although growth accelerated after 2006. Nevertheless, at 35 percent of GDP, the stock of net loans (exclusive of interbank loans) is low compared to other countries in the region (Figure 1). Loans are only 49 percent of banks' total assets, and investment in securities (mostly long-term government securities) another 25 percent. Although housing finance has grown rapidly, it is still low relative to regional peers, ${ }^{3}$ and public entities account for slightly over half of housing loans.

Figure 1. Philippines: Credit-to-GDP

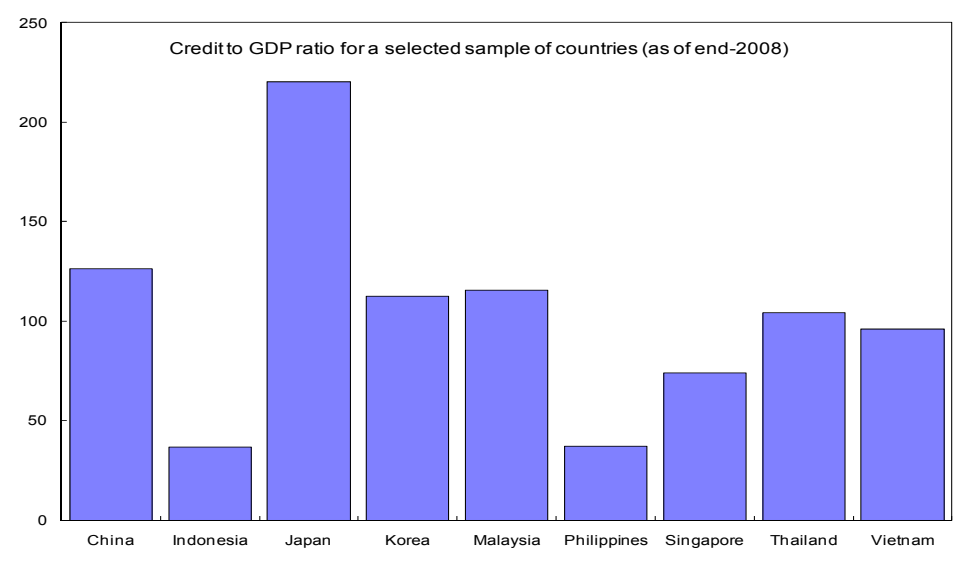

Source: IMF IFS and staff estimates

\section{Nonbank segments are relatively underdeveloped and have grown unevenly.}

- There were 246 companies listed on the Philippine Stock Exchange (PSE) at end2008, a net increase of just twelve since 2003. Market capitalization dropped sharply in 2008 to 54 percent of GDP, about the same level as in 2002 and below that of Thailand and Singapore. The market is not liquid, partly reflecting the small free float of most companies.

- $\quad 45$ mutual funds have P63 billion in assets (among the lowest in Asia), managed by a range of broker-dealers or investment companies (the largest of whom are affiliated with banks). In addition, 115 unit investment trust funds (akin to mutual funds, but operated by banks) have some P100 billion of assets, while bank private asset management or trust departments control another P1.4 trillion in assets.

\footnotetext{
${ }^{3}$ At $4 \frac{1}{2}$ percent of the GDP, housing loans extended by financial intermediaries in the Philippines are higher than Indonesia ( $2 \frac{1}{2}$ percent) but lag Thailand (17 percent) and Malaysia ( 26 percent). There is also financing by developers, which is estimated to be almost equal in size to the lending by financial intermediaries.
} 
- Government securities continue to dominate the debt market and, although corporate debt issues increased in recent years, the corporate debt market remains relatively small (about 4 percent of GDP).

- $\quad$ Despite a large number of insurers and a wide range of products, the market is small (total insurance premium was just over 1 percent of GDP in 2008) and, except for microinsurance, contracted in real terms since 2002.

4. Conglomerates are an important feature of the Philippine economy. Many own companies in telecommunications, energy, property, and retail trade - as well as banking. About 60 percent of bank assets are controlled by banks belonging to conglomerates ( 7 of the 10 largest banks belong to conglomerates). Furthermore, a large proportion of listed companies (estimated at $3 / 4$ of effective market capitalization) also belongs to conglomerates.

\section{B. Recent Macroeconomic Trends and Outlook}

\section{The global financial crisis has affected the economy, though less than in several} export-dependent Asian countries. With exports-to-GDP around 30 percent, the Philippine economy is less driven by exports than many other regional peers. It is still, however, exposed to external shocks through the large flows of workers' remittances (10 percent of GDP) and confidence factors. Following the onset of the crisis, exports declined sharply, remittance growth slowed, and investment and consumption weakened as confidence waned. Macroeconomic policies were adjusted quickly: the central bank cut interest rates by a cumulative 200 bps between December 2008 and July 2009, and the government adopted a fiscal stimulus package to boost investments in infrastructure and social services. Nonetheless, annual GDP growth slowed from 7.1 percent in 2007 to 3.8 percent in 2008, and GDP contracted 2.1 percent (q/q) in the first quarter of 2009. While significant, this impact was smaller than initially feared (Figure 2).

\section{Economic activity and financial markets have now started rebounding, buoyed by resilient remittances, supportive macroeconomic policies and renewed confidence.}

- $\quad$ Growth and inflation: GDP rebounded by 1.7 and 1.0 percent (q/q) in the second and third quarters of 2009, respectively, driven by remittances and a modest recovery in exports, and supported by the fiscal stimulus and low interest rates. Inflation has trended down and is expected to stay near the middle of the BSP's target range of $3 \frac{1}{2} \pm 1$ percent in 2009 .

- $\quad$ Public finances: Fiscal policy has played an important role in supporting activity, but at the cost of a higher fiscal deficit, which is expected to reach 4.4 percent of GDP in 2009 , compared to 1.5 percent in 2008 (IMF definition). 
Figure 2. Philippines: Macroeconomic and Financial Market Developments

GDP Growth

(Quarter-on-quarter, in percent, SA)

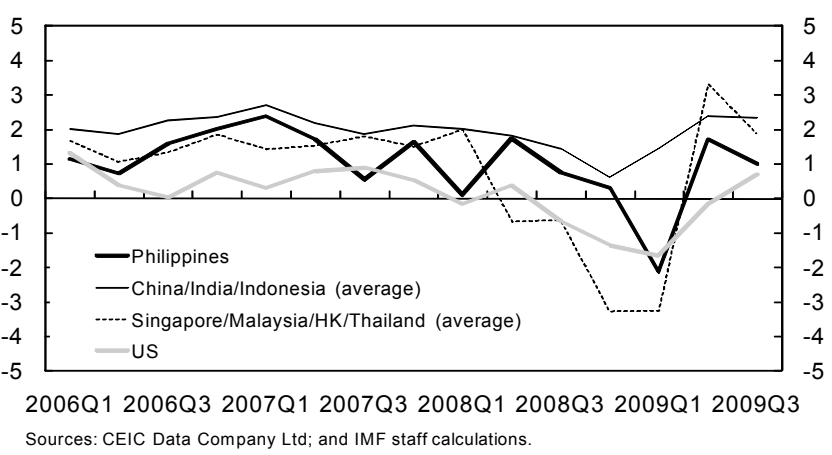

Current Account

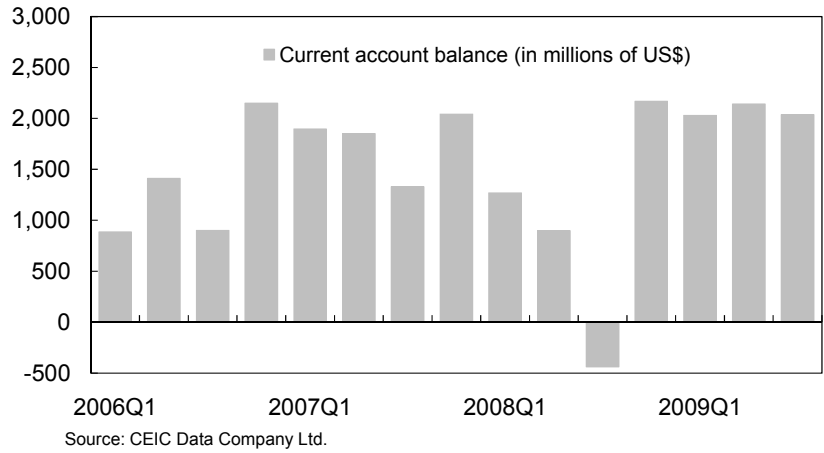

Source: CEIC Data Company Ltd.

International Reserves and Exchange Rate

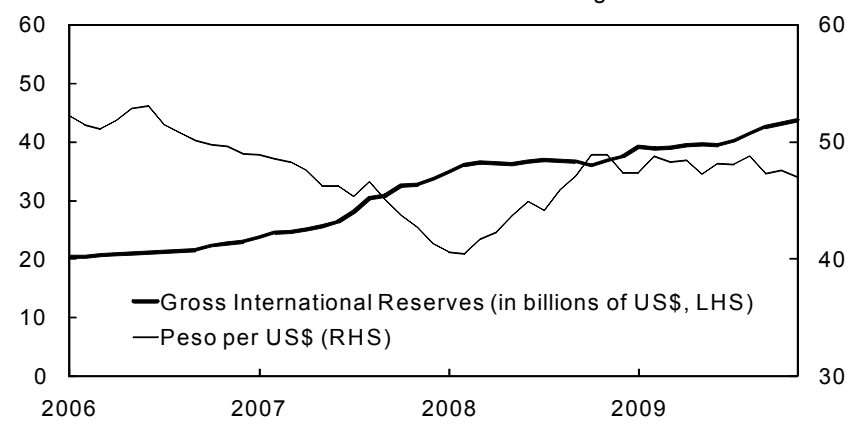

Sources: The Philippines Authorities and CEIC Data Company Ltd.

Interest Rates

(In percent)

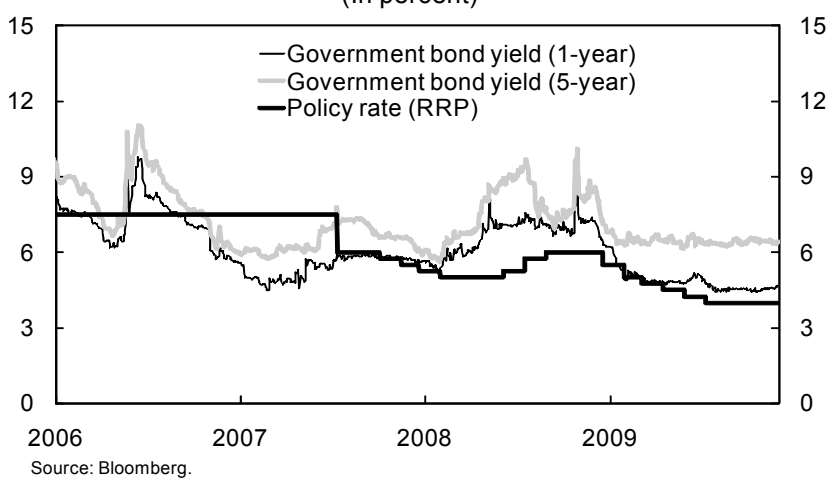

Consumer Price Index

(Year-on-year percent change)

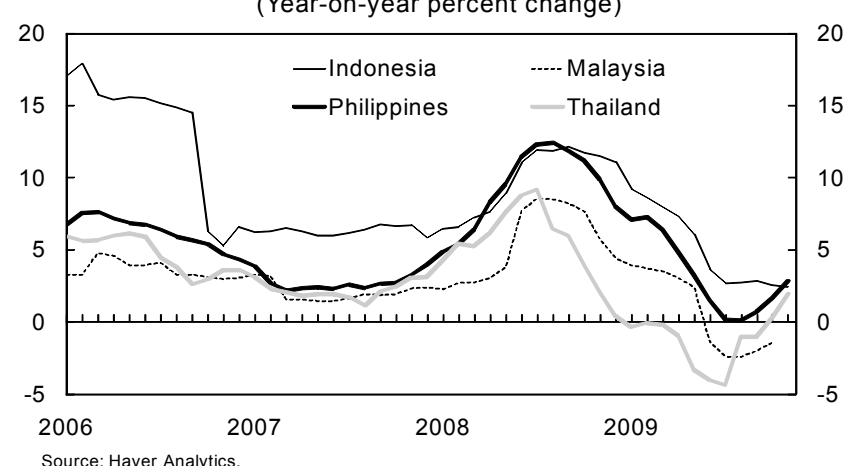

Public Finance
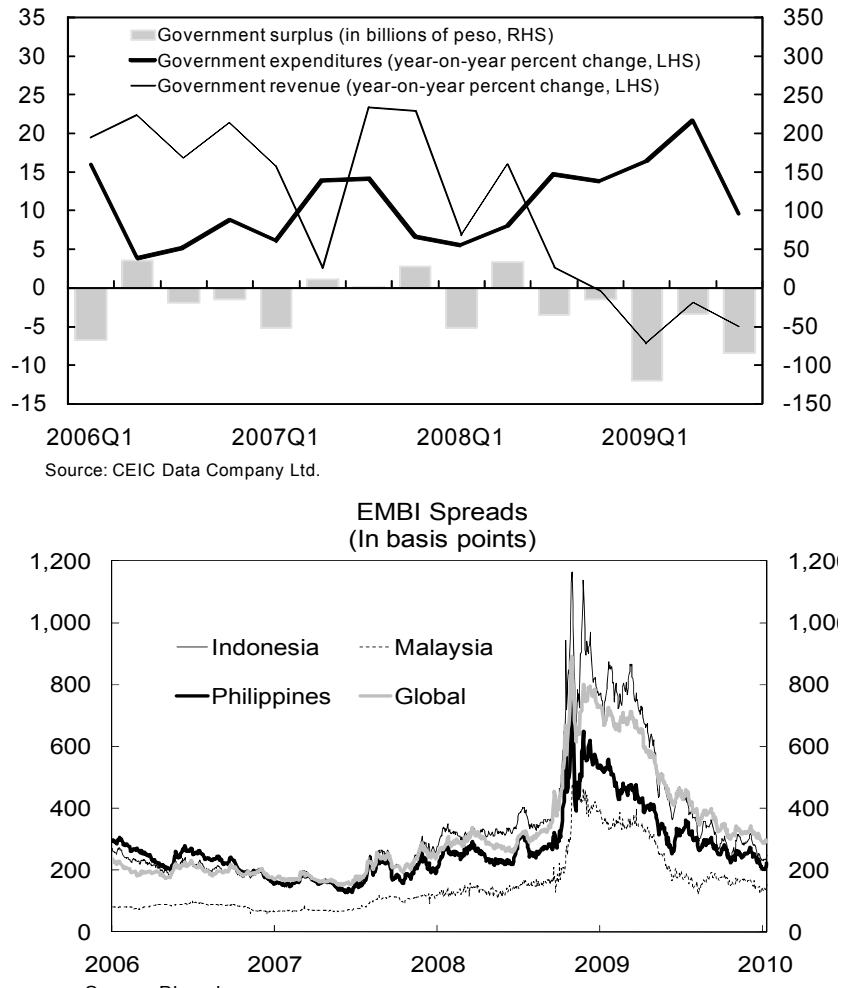

Stock Prices

(Index June $2007=100)$

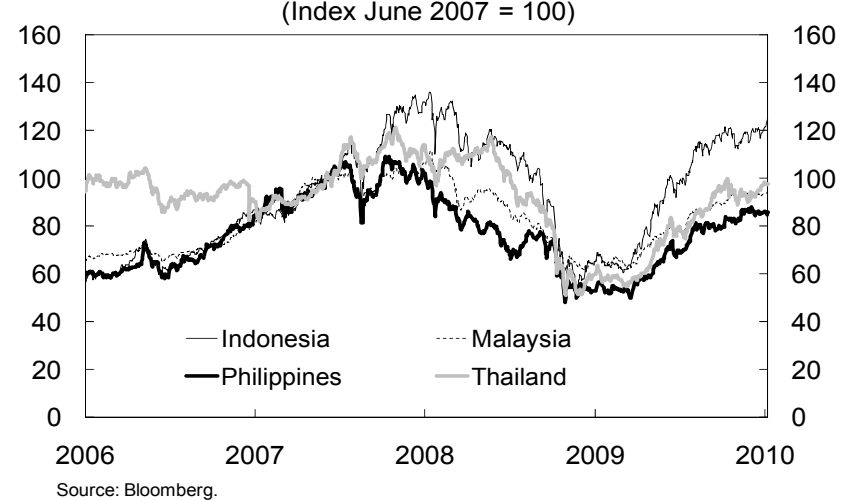


- $\quad$ Financial markets: Stock prices have returned to pre-crisis levels, in line with regional trends. Credit spreads have narrowed, with the EMBI+PHL spread down to around $220 \mathrm{bps}$ from $780 \mathrm{bps}$ during the height of the crisis.

- $\quad$ Balance of payments: The current account remains in surplus. The sharp drop in exports was offset by the decline in commodity prices and imports of intermediate and capital goods, while remittances continued to increase.

7. Economic activity is likely to continue recovering in the near term, albeit only gradually. Growth is forecast to average $3 / 4-1$ percent in 2009 and 3-31/2 percent in 2010 . The recovery would be led by private consumption as consumer confidence continues to improve. Exports and investment are also likely to increase as the global economy recovers.

\section{The Corporate Sector}

\section{The non-financial corporate sector entered the global financial crisis in a} relatively strong position, unlike in the Asian crisis of the 1990s. This reflects a major strengthening of corporate balance sheets over the last decade (Figure 3). ${ }^{4}$

- $\quad$ Earnings and profitability: Strong net sales and slower expenditure growth led to a significant increase in the average rate of return on assets, which is now above the Emerging Asia average. And while corporate earnings declined sharply in 2008, they have started to rebound: the combined net income of listed companies, excluding financials, increased by 50 percent ( $y / y$ ) during the first half of 2009-although this was to some extent driven by one-off gains from asset sales.

- Leverage: The average debt-to-asset ratio fell about 10 percent and the debt structure improved, with the share of both external debt and short-term debt declining sharply. As a result of both de-leveraging and improved earnings, the average debt-to-cash flow ratio fell by more than half from its peak before the Asia crisis, and is now below the average for Emerging Asia.

- Liquidity: The ratio of current assets net of inventories-to-current liabilities (“quick ratio") reached about 150 percent in 2007, an all-time high; and while declining slightly in 2008, it remains above the average for Emerging Asia. This meant that the corporate sector had sufficient liquid assets to deal with the sharp decline in roll-over rates during 2008-09.

\footnotetext{
${ }^{4}$ This analysis covers data on major listed companies and uses data provided by the authorities, IMF, or Moody's KMV.
} 


\section{Following a spike during the height of the global crisis, expected default}

probabilities have declined. Based on the Contingent Claims Analysis (CCA) approach (Figure 4 and Appendix I), expected default probabilities one year ahead spiked right after the collapse of Lehman Brothers but have declined sharply in recent months. Current expected losses from corporate defaults in the Philippines are broadly in line with those in regional peers.

Figure 3. Philippines: Corporate Sector Income and Balance Sheet Indicators
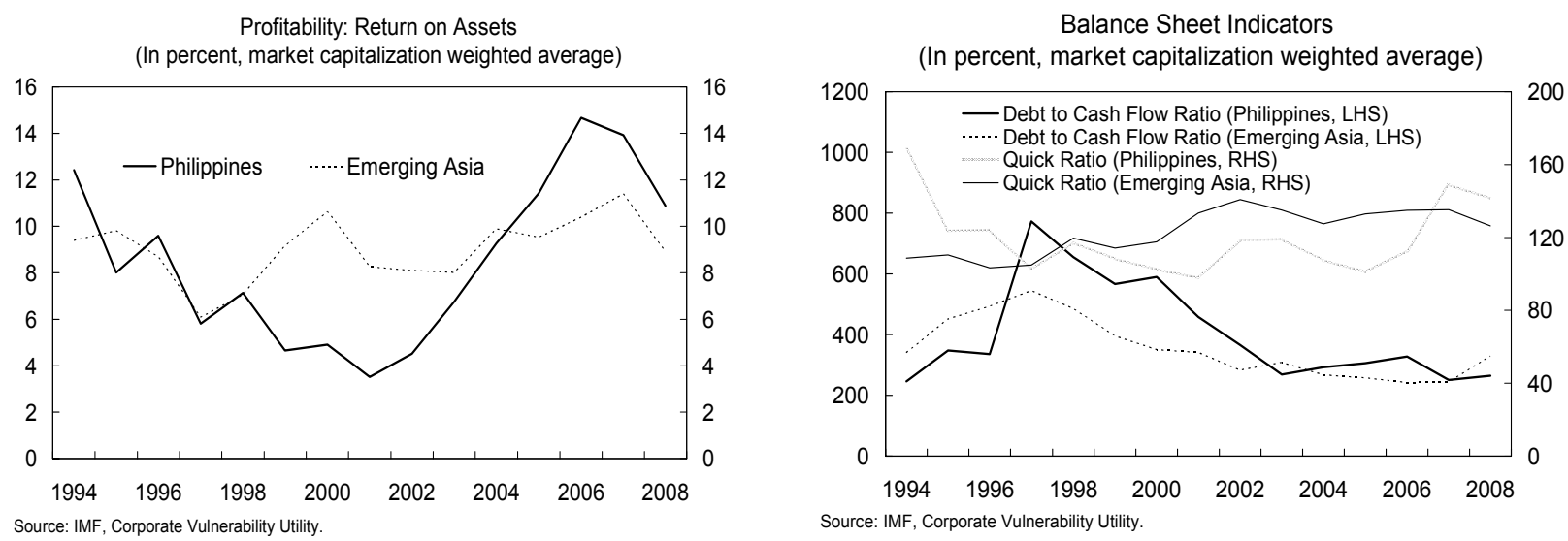

Figure 4. Philippines: Corporate Sector Expected Default Probabilities
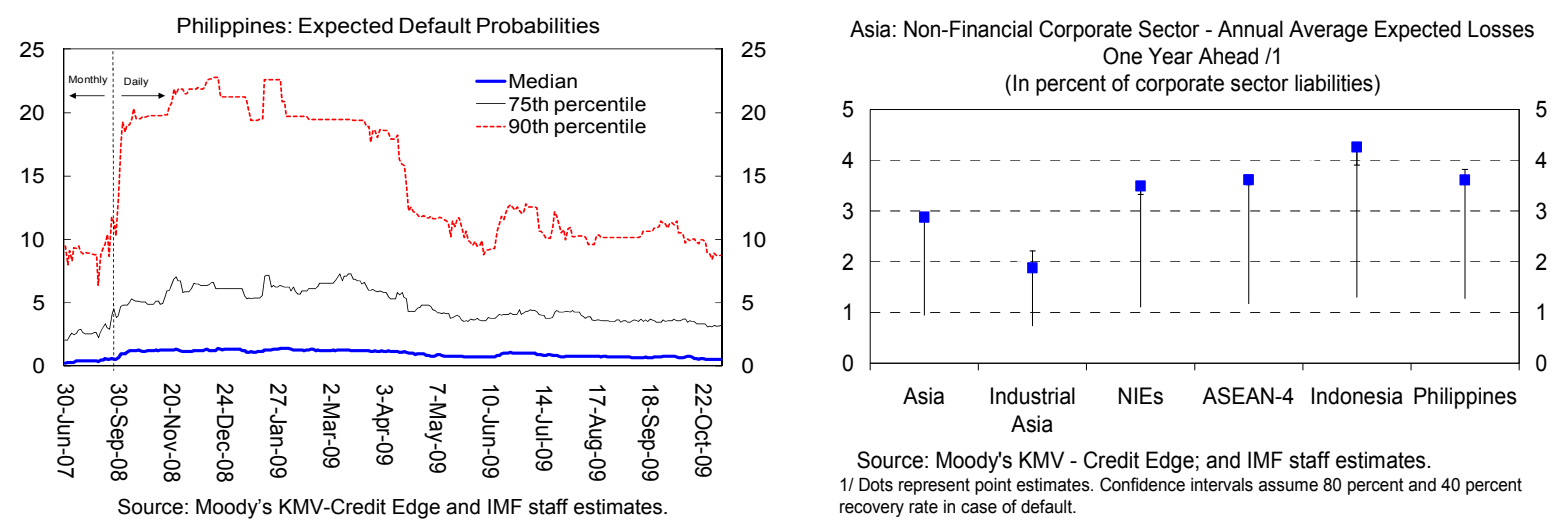

$1 /$ Dots represent point estimates. Confidence intervals assume 80 percent and 40 percent 


\section{BAnKing Sector Stability}

\section{A. Key Risks}

\section{The effects of the global crisis on the Philippine banking sector have thus far}

been mild. This reflects to a large extent the impressive improvement in bank asset quality since the late 1990s on the back of measures taken to clean up banks' balance sheets, including tax and regulatory incentives, ${ }^{5}$ as well as improvements in risk management. As a result, NPLs declined from a peak of 16.9 percent of total loans in 2001 to about 4 percent in 2008-09 (Table 3); and the stock of foreclosed real estate and other property (ROPA) on bank books declined from a high of 6.3 percent of total assets in 2002 to 2.7 percent in June 2009 , as banks gradually disposed of these assets. When the current crisis initially hit, it affected mainly banks' trading books, but these losses were easily absorbed by profits. The second-round effects of the crisis have been lower than expected, although some asset quality deterioration is evident, especially among the smallest and weakest institutions in the system, whose NPL ratio ratios are more than twice that of universal and commercial banks - and rising (Figures 5-6). About 200 of these (mostly rural banks) are currently under PCA. Loans continued to grow during the first half of 2009, albeit at a slowing pace, and banks reported a mild recovery of profits from 2008.

\section{Staff analysis suggests that current risks for Philippine banks are manageable,} due in part to their relatively high capital (CAR over 15 percent):

- $\quad$ Credit risk. NPL net of provisions equal 7.2 percent of capital, and credit concentration tends to be high (Figures 5 and 6). However, government securities account for a large share of assets and counterparty credit risk exposure from derivatives contracts is moderate (Appendix II). In addition, guarantees and credit lines (which are off-balance sheet) were about 14 percent of total assets, much lower than regional peers. ${ }^{6}$

- Interest rate risk. Fixed-rate government securities account for about 25 percent of banks' assets and funding is concentrated in short-term deposits, resulting in substantial duration gaps. For thrifts, rural, and cooperative banks, this risk is magnified by the larger share of real estate loans in their portfolios ( 34 percent, as opposed to 12 percent at universal and commercial banks). ${ }^{7}$

\footnotetext{
${ }^{5}$ These allowed banks to sell non-performing assets to Special Purpose Vehicles (SPVs—banks sold around 28 percent of their NPAs to SPVs during the last decade), and deferring losses made on these asset sales over 10 years.

${ }^{6}$ This ratio was 115.6, 14.8, and 48.5 percent for Thailand, Indonesia, and Malaysia (Source: Bankscope).

${ }^{7}$ Typically, interest rates on mortgage loans are fixed during the first years.
} 


\section{Table 3. Philippines: Financial Soundness Indicators for the Banking System}

(In percent, unless otherw ise indicated)

\begin{tabular}{lllllllll}
\hline 2001 & 2002 & 2003 & 2004 & 2005 & 2006 & 2007 & 2008 & $\begin{array}{l}\text { June } \\
2009\end{array}$ \\
\hline
\end{tabular}

\section{Capital adequacy $1 /$}

Regulatory Tier I capital to risk-weighted assets* $v$

Regulatory Tier II capital to risk-weighted assets* $v$

Regulatory capital to total assets $v$

\section{Asset composition \\ Loans to Residents \\ Loans to Non-Resident \\ Gross asset position in derivatives to capital \\ Gross liability position in derivatives to capital \\ FXloans to total loans}

\section{Asset quality}

NPL to gross total loans*

NPLs net of provisions to capital*

Specific provisions to distressed assets $2 /$

Specific provisions to gross lending

\section{Earnings and profitability}

$\mathrm{ROA}^{*}$

$\mathrm{ROE}^{*}$

Net interest income to gross income*

Noninterest expenses to gross income*

Personnel expenses to noninterest expenses

Trading and fee inco me to total inco me

Yield on earning assets less cost of funds

Net interest income to average earning assets

Liquidity

Liquid assets to total assets*

Liquid assets to total short-term liabilities*

Customer deposits to to tal (non-interbank) loans

FX denominated liabilities to total liabilities

Sensitivity to market risk

Net open positions in FX to capital ${ }^{*}$

$\begin{array}{lllllllll}15.6 & 16.9 & 17.5 & 18.4 & 17.6 & 18.1 & 15.7 & 15.5 & 15.3 \\ 14.5 & 15.6 & 15.0 & 15.8 & 15.3 & 14.9 & 13.1 & 12.6 & 12.4 \\ 1.9 & 2.1 & 3.0 & 3.2 & 2.9 & 3.5 & 3.0 & 3.3 & 3.3 \\ 10.4 & 10.6 & 11.1 & 11.3 & 10.7 & 10.4 & 10.3 & 10.7 & 10.9\end{array}$

$\begin{array}{lllllllll}91.0 & 90.1 & 91.0 & 92.2 & 89.5 & 85.9 & 88.1 & 91.4 & 89.9\end{array}$

$\begin{array}{lllllllll}9.0 & 9.9 & 9.0 & 7.8 & 10.5 & 14.1 & 11.9 & 8.6 & 10.1\end{array}$

not available

$18.4 \quad 8.4$

$7.4 \quad 4.4$

$\begin{array}{lllllllll}27.1 & 26.8 & 25.4 & 23.9 & 23.3 & 23.0 & 19.5 & 7.7 & 18.4\end{array}$

$\begin{array}{ccccccccc}16.9 & 14.6 & 13.9 & 12.6 & 8.6 & 6.1 & 4.9 & 4.1 & 4.1 \\ 42.4 & 29.6 & 32.3 & 23.1 & 13.6 & 10.8 & 8.1 & 7.7 & 7.2 \\ 22.5 & 25.8 & 23.0 & 27.3 & 29.7 & 26.4 & 27.7 & 31.5 & 32.2 \\ 6.5 & 7.2 & 5.9 & 6.7 & 5.3 & 3.5 & 3.0 & 2.5 & 2.4\end{array}$

$\begin{array}{lllllllll}0.4 & 0.8 & 1.1 & 0.9 & 1.1 & 1.3 & 1.3 & 0.8 & 1.2\end{array}$

$\begin{array}{lllllllll}3.2 & 5.8 & 8.5 & 7.1 & 8.7 & 10.6 & 10.7 & 6.9 & 11.0\end{array}$

$\begin{array}{lllllllll}59.8 & 57.3 & 53.6 & 65.4 & 65.9 & 60.4 & 59.8 & 68.4 & 68.1\end{array}$

$\begin{array}{lllllllll}75.0 & 69.5 & 62.6 & 68.1 & 65.5 & 64.0 & 65.2 & 74.2 & 67.5\end{array}$

$\begin{array}{lllllllll}34.9 & 36.6 & 38.6 & 36.6 & 35.2 & 34.2 & 34.4 & 34.2 & 33.4\end{array}$

$34.9 \quad 36.6 \quad 38.6$

$27.5 \quad 34.9 \quad 32.1$

$3.4 \quad 3.5 \quad 3.4$

$3.5 \quad 3.6 \quad 3.5$

24.4

$\begin{array}{lllll}24.7 & 29.4 & 28.5 & 22.2 & 26.0\end{array}$

$\begin{array}{lll}3.4 & 3.9 & 4.3\end{array}$

4.4

4.6

4.5

5.2

4.9

$\begin{array}{lllllllll}30.3 & 34.4 & 33.8 & 39.9 & 38.8 & 41.5 & 39.1 & 47.1 & 38.0 \\ 40.9 & 42.6 & 44.0 & 50.8 & 52.0 & 52.0 & 51.2 & 64.2 & 56.4 \\ 133.0 & 143.4 & 147.4 & 158.4 & 163.7 & 188.8 & 176.7 & 178.3 & 150.2 \\ 38.6 & 38.4 & 38.1 & 40.0 & 38.9 & 32.9 & 27.3 & 28.7 & 28.2\end{array}$

Source:BSP

* Included in the "core and encouraged set" of FSIs.

V 2009 data are for $M$ arch.

2/ Distressed assets consist of NPL, ROPA, Non-Performing SCR, Non-Current Assets Held for Sale, and Performing Restructured Loans. 
Figure 5. Philippines: Largest Banks' Key Risk Indicators
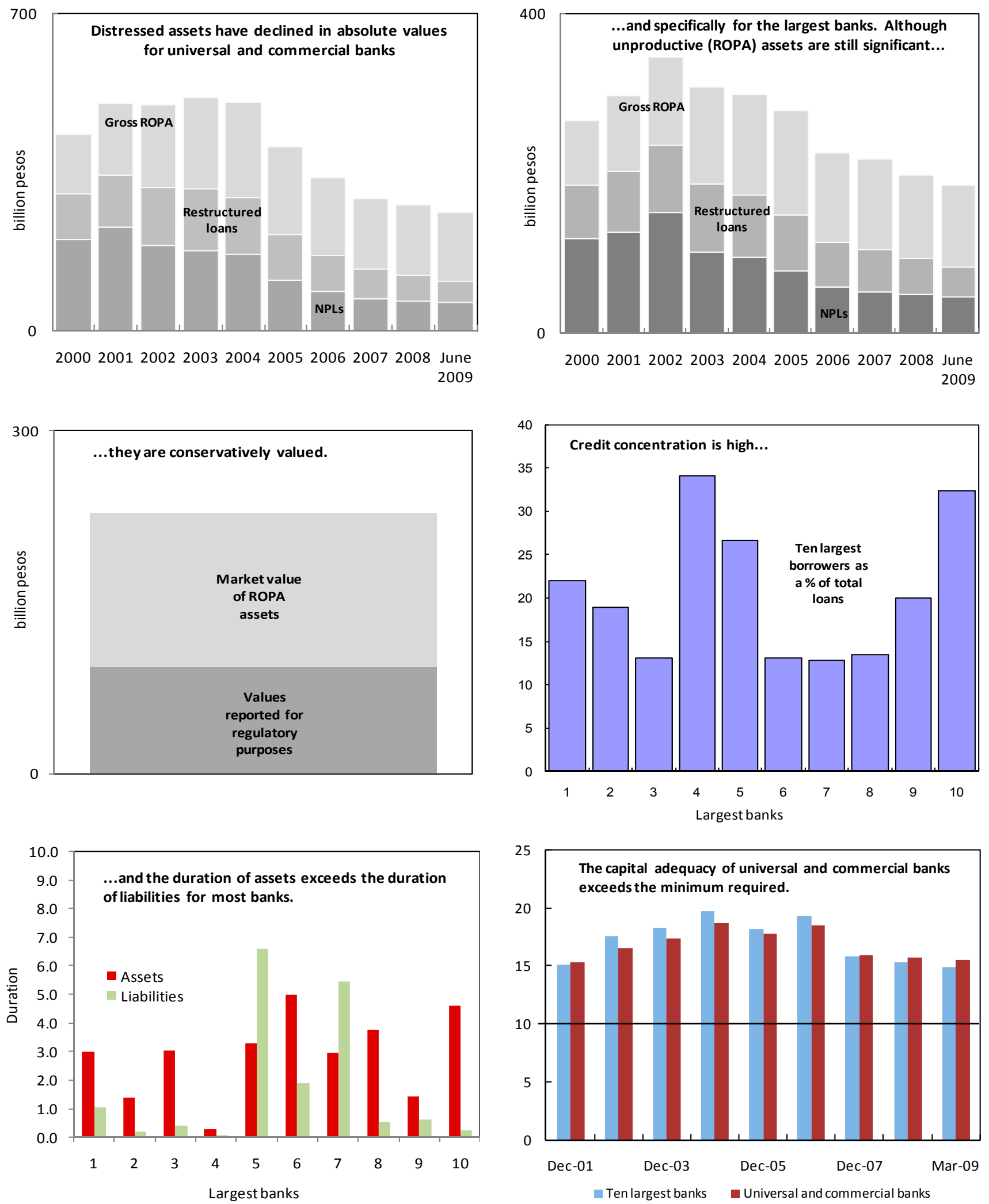

Source: BSP and IMF estimates. 
Figure 6. Philippines: Thrift, Rural, and Cooperative Banks' Key Risk Indicators
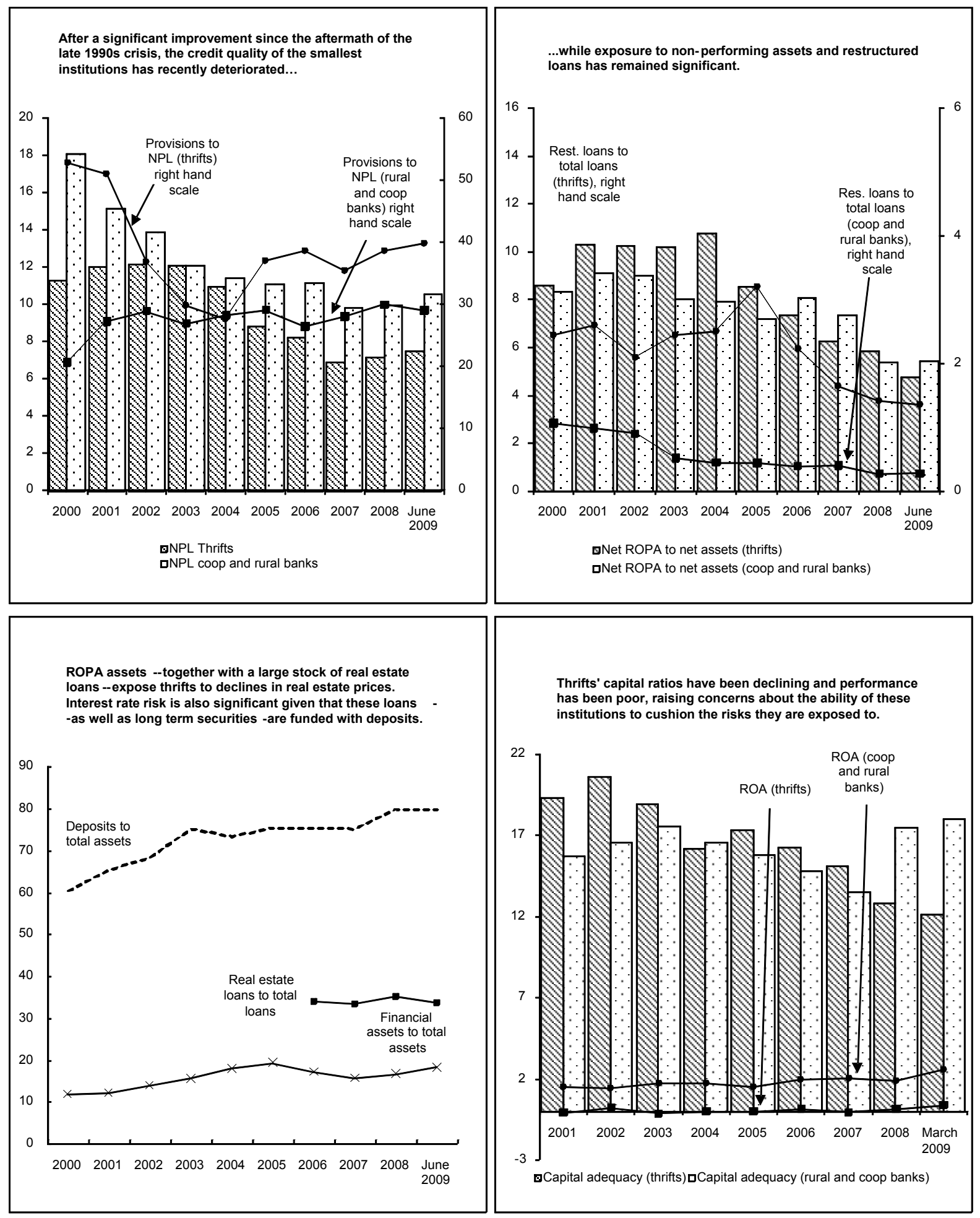

Source: BSP and IMF estimates. 
- $\quad$ Foreign exchange risk. Open positions are capped at the lowest of 20 percent of unimpaired capital or US\$50 million, applied on a consolidated basis (positions can be larger at the solo bank level). Banks' solo net open foreign exchange position was about 5 percent of capital at June 2009 (Table 3), but it tends to fluctuate substantially between long and short.

\section{Exposure to other risks is small:}

- $\quad$ Real estate prices. Loan-to-value ratios are generally conservative. The level of ROPA on bank balance sheets is relatively low and, for larger banks, conservatively valued. ${ }^{8}$ Moreover, ROPA assets are subject to 150 percent risk weight.

- $\quad$ Risk from derivatives. Most derivatives are plain vanilla and risks are limited by license requirements. Following the global financial crisis, banks pulled back from structured products, such as credit-linked notes, and closed many leveraged positions (Appendix II).

- Off-balance sheet exposures other than derivatives and credit guarantees, namely unit trust funds, which match pools of investors with specific projects, have grown to the equivalent of 20 percent of banks' on-balance sheet assets. However, since returns to investors are not guaranteed, these funds entail limited risks for banks.

- $\quad$ Equity price risk. Exposure is only about 2 percent of banks' trading portfolio.

- Liquidity risk. Banks hold large stocks of government securities (which can be easily repo'd with the BSP) and their funding is concentrated in core deposits. Foreign currency liquidity risk is also limited by a liquid asset requirement of 30 percent of foreign currency deposits.

- Cross-border risks. Banks mostly raise funds and lend domestically. ${ }^{9}$ Foreign banks' market share is only about 10 percent, and there are limits on repatriation of profits.

13. Although the economic recovery would reduce risks further, vulnerabilities are likely to remain somewhat elevated in the near term. With GDP growth still sluggish and inflation and interest rates expected to stay low in 2010, bank profits will likely remain below pre-crisis levels. Moreover, high operating costs to revenue - due in part to the expense of

\footnotetext{
${ }^{8}$ The historical book value of ROPA assets (used for reported capital adequacy ratios) of the largest banks ranged between 0.4-4 times lower than the present market value of these assets (as reported under IAS).

${ }^{9}$ While the largest banks have subsidiaries and branches abroad, these are used to channel remittances and not for cross-border credit exposure.
} 
maintaining infrastructure across a fairly dispersed geographical area - may weigh on bank earnings and internal capital generation. ${ }^{10}$ Additionally, there are tail risks that could have a significant impact (summarized in the Risk Assessment Matrix in Table 4). ${ }^{11}$

\section{B. Stress Tests}

\section{Stress tests assessed the vulnerability of the largest banks to the tail risks}

discussed above. ${ }^{12}$ The exercise was conducted in conjunction with the BSP and assessed the impact of the following shocks (assumed to be permanent) on capital adequacy or liquidity ratios:

\section{- Credit risk from major macroeconomic shocks. ${ }^{13}$}

- remittances decline by 12 percent $y / y$;

- sovereign spreads increase of $250 \mathrm{bps}$;

○ export values decline by 50 percent; and

a combination of all the above shocks.

- Concentration risk: failure of each bank's largest, two largest, and five largest borrowers; and failure of the five largest borrowers in the system.

- Interbank risk: the default of a large bank.

- Market risks:

- an increase of 200 bps and 500 bps in interest rates;

- a 50 percent appreciation or depreciation of the exchange rate.

- Liquidity risk: a combined deposit withdrawal, drawdown of committed credit lines, and haircut of debt securities of 10 percent each; and a similar shock of 25 percent.

\footnotetext{
${ }^{10}$ Average operating costs are about 3.4 percent of total assets, the second highest after Indonesia (4.4 percent) among a sample of banking systems in the region (Thailand, Malaysia, India, China, Japan, Korea, Singapore and Vietnam (source: Bankscope).

${ }^{11}$ The ex ante probabilities (low-medium-high) are subjective assessments and, since the Matrix includes only tail risks, are generally below 50 percent. Their expected impact is based on the stress tests.

12 The largest banks were chosen because of their systemic importance, and together account for approximately two-thirds of total assets.

${ }^{13}$ See Appendix III for a description of the methodology.
} 
Table 4. Philippines-Risk Assessment Matrix

\begin{tabular}{|c|c|c|}
\hline \multirow[b]{2}{*}{$\begin{array}{l}\text { Nature/Source of Main } \\
\text { Threats }\end{array}$} & \multicolumn{2}{|c|}{ Overall Level of Concern } \\
\hline & $\begin{array}{l}\text { Likelihood of Severe Realization } \\
\text { of Threat (in the next } 2 \text { years) }\end{array}$ & $\begin{array}{l}\text { Expected Impact on Financial Stability if } \\
\text { Threat is Realized }\end{array}$ \\
\hline $\begin{array}{l}\text { 1. A rise in interest rates (e.g., } \\
\text { through a sharp hike in policy } \\
\text { rates and/or a higher sovereign } \\
\text { risk premium). }\end{array}$ & $\begin{array}{l}\text { MEDIUM } \\
\text { - Public debt ( } 60 \text { percent of GDP) is } \\
\text { high. The } 2009 \text { budget deficit (IMF } \\
\text { definition) is projected at } 4.4 \text { percent of } \\
\text { GDP, up from } 1 \frac{1}{2} \text { percent last year. } \\
\text { - Fiscal slippage due to the recent } \\
\text { typhoons could create concerns about } \\
\text { fiscal credibility and raise risk premiums. } \\
\text { - On the other hand, with the } \\
\text { moderate projected pace of economic } \\
\text { rebound, policy rates are likely to be } \\
\text { raised only gradually. }\end{array}$ & $\begin{array}{l}\text { LOW-MEDIUM (based on stress test results) } \\
\text { - Banks have large duration gaps since they } \\
\text { fund long-term assets with short-term deposits. } \\
\text { B Banks' security portfolio represents over } 20 \\
\text { percent of bank assets. Among the largest } 10 \\
\text { banks, over } 60 \text { percent of these securities are } \\
\text { holdings of government bonds. } \\
\quad \text { Following the last financial turmoil, some } \\
\text { banks have reclassified some of these bond } \\
\text { holdings from their trading account to their hold-to- } \\
\text { maturity and available-for-sale accounts. This } \\
\text { means any losses would not be realized } \\
\text { immediately. }\end{array}$ \\
\hline $\begin{array}{l}\text { 2. A sustained decline in real } \\
\text { estate prices. }\end{array}$ & $\begin{array}{l}\text { LOW-MEDIUM } \\
\text { - After sharp falls following the crisis } \\
\text { of the late } 1990 \text { s, real estate prices } \\
\text { have grown significantly during the last } \\
\text { decade. During } 2009 \text {, however, growth } \\
\text { in prices flattened. } \\
\text { - On the other hand, there is no } \\
\text { evidence of a real estate bubble, and a } \\
\text { recent law allowing REITs is likely to } \\
\text { have a positive impact on investment } \\
\text { demand, which could limit the downward } \\
\text { trend in prices. }\end{array}$ & $\begin{array}{l}\text { LOW (Based on analysis in sections B and C) } \\
\text { - Lending to property developers would slow } \\
\text { and credit quality property sector loans could } \\
\text { deteriorate. } \\
\quad \text { The largest banks still hold stock of } \\
\text { foreclosed property (ROPA). However, these } \\
\text { assets are conservatively booked in their balance } \\
\text { sheets (a cushion of about } 40 \text { percent or more, } \\
\text { depending on the bank). The smaller banks, } \\
\text { however, have generally higher ROPA and lower } \\
\text { provisions. }\end{array}$ \\
\hline $\begin{array}{l}\text { 3. A severe recession (growth } \\
\text { between }-2 \text { and }-6 \text { percent) } \\
\text { triggered by a decline in } \\
\text { remittances, exports, consumer } \\
\text { confidence, or a combination of } \\
\text { these factors. }\end{array}$ & $\begin{array}{l}\text { LOW } \\
\text { - Baseline projections suggest GDP } \\
\text { growth rates of } 0.8 \text { percent and } 3.2 \\
\text { percent in } 2009 \text { and } 2010 \text {, respectively. } \\
\text { Growth has proved stronger than } \\
\text { expected due in part to supportive } \\
\text { policies. } \\
\text { - However, there are still downside } \\
\text { risks to the baseline, stemming from } \\
\text { weaker than expected global growth or } \\
\text { a sharp rise in interest rates (see } \\
\text { case 1). }\end{array}$ & $\begin{array}{l}\text { MEDIUM (based on stress test results) } \\
\text { - NPLs tend to increase as economic activity } \\
\text { weakens. An increase in NPLs would require } \\
\text { additional provisions, which would affect profits } \\
\text { and potentially capital. }\end{array}$ \\
\hline
\end{tabular}




\begin{tabular}{|c|c|c|}
\hline $\begin{array}{l}\text { 4. Failure of a large economic } \\
\text { group. }\end{array}$ & $\begin{array}{l}\text { LOW } \\
\text { - Conglomerates are large and very } \\
\text { diversified. The corporate sector in } \\
\text { general is much stronger than at the } \\
\text { time of the last crisis and much more } \\
\text { liquid. }\end{array}$ & $\begin{array}{l}\text { HIGH (based on stress test results) } \\
\text { - Banks' exposures to large conglomerates is } \\
\text { high. In case of failure, some of the largest banks } \\
\text { would see their Tier } 1 \text { capital wiped out. Failure of } \\
\text { more than one large economic group would } \\
\text { seriously impair the capital of several major banks. }\end{array}$ \\
\hline $\begin{array}{l}\text { 5. Renewed turmoil in international } \\
\text { financial markets that affect } \\
\text { international banks and causes a } \\
\text { sudden stop/reversal of capital } \\
\text { inflows with a severe impact on } \\
\text { asset prices (in particular } \\
\text { exchange rate). }\end{array}$ & $\begin{array}{l}\text { LOW } \\
\text { - Recent WEO and GFSR point to a } \\
\text { recovery in global financial and credit } \\
\text { markets. }\end{array}$ & $\begin{array}{l}\text { 1. Foreign exchange risk: MEDIUM (based on } \\
\text { stress tests results) } \\
\text { - Banks have moderate net open foreign } \\
\text { exchange positions that fluctuate frequently } \\
\text { between short and long. } \\
\text { 2. Interest rate risk: LOW-MEDIUM (based on } \\
\text { stress test } 2 \text { and 7) } \\
\text { 3. Cross-border risks (including through } \\
\text { counterparty risks): LOW (based on FSI) } \\
\text { - Banks have reduced their exposure to } \\
\text { international banks and written off the losses } \\
\text { suffered during the financial turmoil. } \\
\text { 4 Liquidity risk: LOW (based on stress test 9) } \\
\text { - } \quad \text { Banks depend mainly on deposit funding. }\end{array}$ \\
\hline $\begin{array}{l}\text { 6. Illiquidity or insolvency of a } \\
\text { large bank. }\end{array}$ & $\begin{array}{l}\text { LOW } \\
\text { - Preliminary analysis shows a few } \\
\text { large or medium-sized banks could be } \\
\text { undercapitalized under extreme } \\
\text { scenarios. }\end{array}$ & $\begin{array}{l}\text { LOW (based on stress test results and only } \\
\text { assessing the direct impact) } \\
\text { - The interbank market is very shallow and } \\
\text { direct bank exposures to other banks are small. } \\
\text { - The BSP has facilities and flexibility to } \\
\text { address a sudden liquidity shortfall. } \\
\text { - The PDIC can provide financial assistance in } \\
\text { systemic risk cases. }\end{array}$ \\
\hline
\end{tabular}


15. The results suggest that the major banks are resilient to extreme macroeconomic scenarios, given their high capital buffers. ${ }^{14}$ Only in the case of the export and the combined shocks scenarios does the CAR of a few banks slip under the minimum requirement. Despite high credit concentration, most banks would be resilient to the failure of their single largest borrower, or even of the five largest borrowers in the system (as not all banks are exposed to these borrowers to the same degree); but the CAR of most banks would fall below the minimum if the five largest borrowers of each of them failed - an extreme scenario, especially since banks lend mainly to highly-diversified, highly-rated companies. Furthermore, given limited interbank exposures, the failure of any one bank would not significantly impact the others (stress tests, of course, measure only the direct impact; the indirect effects on the economy could be more significant if a large bank were to fail).

16. Banks are also resilient to market and liquidity risks, except in the most extreme scenarios. All banks would be resilient to a permanent 200 bps parallel shift of the yield curve, although a permanent 500 bps shift would significantly reduce the CAR of several banks. Banks would also be sensitive to large currency swings, depending on whether their position would be short or long. Banks can withstand a liquidity event characterized by withdrawals, drawdowns, and haircuts of 10 percent. However, the more extreme liquidity shocks (i.e., a 25 percent deposit withdrawal) would exhaust the liquid assets of a limited number of banks.

\section{BAnKIng System SAFETy Nets}

\section{A. Bank Rehabilitation and Resolution}

17. Major steps were taken to address the 2002 FSAP recommendations in this area. PDIC charter amendments (effective June 2009) partially relaxed bank secrecy of deposits and now allow the PDIC and BSP to look into individual deposit accounts during an examination in case of unsafe and unsound banking practices. The Financial Sector Forum (FSF), established in 2004 and comprising the BSP, PDIC, SEC and Insurance Commission, has significantly enhanced information sharing and coordination. In addition, the BSP issued a new PCA regulation (circular 523) in 2006; as a result, banks under PCA increased from less than 20 to some 200 by June 2009. However, of the 270 banks placed in PCA since 2006, only 14 graduated and 56 were placed under receivership.

18. This progress was particularly notable, given that the framework still suffers from weaknesses in legal powers and protection (see $\uparrow 30$ ).

\footnotetext{
${ }^{14}$ In all cases, the post-shock capital ratios were estimated assuming zero profits - a usual assumption in stress testing.
} 
- The PCA basis was expanded to include undercapitalization relative to risk-weighted assets or deposits, a low CAMELS or management rating, and serious supervisory concerns. ${ }^{15}$ Business improvement plans and governance reform plans were added as corrective measures. However, although the BSP has the authority to restrict dividends and activities, the PCA regulation is not progressive-i.e., it does not mandate increasingly severe measures as a bank's CAR or leverage worsens. ${ }^{16}$ Rather, sanctions are imposed for unreasonable delay or after a bank has not complied with its MOU (PCA "failure").

- The periods for corrective actions are overly long. In case of supervisory concerns following an examination, a bank is obliged to take "required" (in case of safety and soundness concerns) or "expected" actions. "Required" actions should be taken within 90 days; the timeline for "expected" actions is not defined, and often stretches over several months. If a bank has failed to take "required" actions, or meets the conditions for PCA under circular 523, is it placed under PCA. Once under PCA, a bank has 30 days to submit an MOU, and 90 days to implement it. While the bank is encouraged by the BSP to correct its deficiencies within one year, it may be allowed a maximum of 3 years under the MOU if capital deficiencies are very large. ${ }^{17}$

- The BSP's authority to place a bank in receivership or suspend shareholder rights, even when a bank is very close to failure, is strictly circumscribed in the law. PCA failure of a critically undercapitalized bank does not necessarily mean that a bank goes into conservatorship or receivership; the conditions for conservatorship or receivership as defined in the law do not include a specific capital threshold. ${ }^{18}$ Moreover, the law or regulations do not specify a time period within which critically undercapitalized banks must be capitalized or be put into receivership. Furthermore, once a bank is placed in receivership there is a 90-day period during which shareholders could seek to rehabilitate their failed bank.

\footnotetext{
${ }^{15}$ Previously, Circular 181 (1998) only required a PCA program in case of undercapitalization relative to the minimum required level of capital.

${ }^{16}$ Circular 181 - which is still in force - does specify mandatory sanctions that increase in severity with the size of shortfall relative to minimum capital levels. However, these trigger points at which action must be taken are too weak (i.e., the bank is already very close to failure), whereas in many other countries, mandatory sanctions kick in on the basis of shortfalls in CAR, if not before.

${ }^{17}$ This shortcoming is partly remedied by new BSP guidelines (2009) that direct supervisors to request immediate recapitalization when a bank has negative CAR. Failure to recapitalize could result in receivership or sanctions. Furthermore, at least 30 percent of the required recapitalization must be concluded within one year.

${ }^{18}$ For receivership, these are: inability to pay its liabilities during normal conditions; insufficient realizable assets to meet liabilities; probable losses to its depositors or creditors; or willful violation of a cease and desist order involving fraud or a dissipation of assets. Illiquidity is the only basis for conservatorship.
} 
19. The BSP and PDIC, well aware of these constraints, have proposed amendments to the relevant legislation. These include:

- $\quad$ Additional sanctions, such as suspension, removal, or disqualification of directors and officers responsible for violations.

- $\quad$ Additional grounds for receivership, including deposit dormancy exceeding 60 days, suspension of deposit payments, and refusal to submit to examination.

- $\quad$ Enhanced resolution powers - if realizable assets are insufficient to cover liabilities, the BSP may direct shareholders to increase capital within 90 days; in case of noncompliance, the BSP may direct the bank to accept investments, merge, or consolidate.

- $\quad$ Limitation on issuance of restraint or injunction - these would be limited to a court of appeals.

20. The proposed amendments would address most of the remaining shortcomings, but they and the PCA framework could be strengthened further. The PCA regulation should be more progressive, i.e., with increasingly severe mandatory and discretionary actions based on worsening CAR (or other risk) triggers. The law should establish a capital threshold above insolvency as the point at which authorities take full control of a bank for restructuring (or at least official administration), as recommended in the 2002 FSAP. ${ }^{19}$ The rehabilitation period allowed owners during receivership should be eliminated. And the resolution framework should allow for a bridge bank.

\section{B. Deposit Insurance}

21. Since the initial FSAP, legal amendments expanded deposit insurance coverage and provided the PDIC with additional powers. Key changes include:

- $\quad$ an increase in maximum deposit insurance coverage from P100,000 to P250,000 in 2004 and from P250,000 to P500,000 in 2009;

- $\quad$ stiffer penalties and the ability to issue cease-and-desist orders for unsafe and unsound banking practices;

- $\quad$ power to conduct regular examinations (with BSP approval) and special examinations in coordination with the BSP in case of impending bank closure;

\footnotetext{
${ }^{19}$ This threshold is often set at half the required Tier 1 CAR. The US uses a leverage ratio (2 percent of tangible equity to assets).
} 
- $\quad$ authority to examine deposit accounts in case of unsafe and unsound practices; and

- $\quad$ power to exclude certain deposits from coverage.

22. Nonetheless, bank secrecy remains a hindrance to the PDIC's ability to fulfill its duties effectively. The initial FSAP had recommended enhancing PDIC coordination with the BSP and relaxation of bank secrecy. While the PDIC charter amendments and the creation of the FSF have improved the former, access to deposit information is still limited: the recent Legacy Bank group failure highlighted that, despite operational improvements in claims processing, prompt payouts can be hampered by the PDIC's lack of timely access to individual deposits (as well as by the often poor state of records by the time the PDIC has been appointed receiver). For the PDIC to play its role effectively, it should be given access to asset and individual deposit information at an early stage when the viability of a bank is in question.

23. The increase in deposit insurance coverage calls for enhanced powers to limit risks and ensure reserve adequacy. Deposit insurance now covers 97 percent of all deposit accounts and about 31 percent of the monetary value of deposits. Actual reserves are $1 \frac{1}{2}$ percent of total deposits, compared with a PDIC target of 2 percent (determined on the basis of the likely insurance costs of expected closures and an additional reserve for unexpected bank failures). During a transitional three-year period following the increase in coverage from P250,000 to P500,000, the government is to cover the second P250,000 of any deposit payouts while the PDIC is building up its reserves to the target level (benefiting from certain tax savings). In addition, PDIC can borrow from the BSP, from the market (up to two times reserves) with a government guarantee, or directly from the government, with no limit. These safeguards help ensure that PDIC would be able to raise the required liquidity in case of need. Still, it would be useful to give the PDIC the authority to raise premiums and, in particular, charge risk-based premiums.

\section{Liquidity and Risk Capital Assistance}

24. Since the initial FSAP, the amount of financial assistance by the BSP to troubled financial institutions has declined sharply. At end-2001, in the aftermath of the Asian crisis, financial assistance to banks by the BSP (either directly or through loans to the PDIC) amounted to 16 percent of reserve money. By end-2007, this had declined to around 9 percent, of which only 1 percent was direct support through the Emergency Liquidity Assistance (ELA) facility. There have also been improvements in BSP procedures for collateral submission and monitoring. 
25. While the ELA facility has many good design features, some conditions are too lenient. ELA may be up to 50 percent of the deposits of a bank under stress - provided it is solvent — secured by acceptable assets. ${ }^{20}$ A 2006 regulation further specifies that ELA cannot exceed 180 days and carries a penalty rate (BSP lending rate plus 2 percentage points).

Furthermore, banks receiving ELA may not expand loans or declare dividends, and are under intensified supervision. However, banks with CAR under 6 percent may also receive ELA if they submit a business improvement plan within 6 months, and those with negative CAR may receive ELA if they are complying with an approved rehabilitation plan. These aspects of the regulation should be reconsidered. A critically undercapitalized institution should only be given very short-term central bank liquidity, in order to enable an orderly resolution; ${ }^{21}$ longer-term risk capital assistance should only be provided by the government or PDIC in the context of resolution, in order to ensure public accountability. And any uncollateralized liquidity support by the BSP should be granted only with government guarantees. ${ }^{22}$

\section{Crisis Preparedness and Crisis Management Arrangements}

\section{Appropriate arrangements are in place for cross-sector supervisory cooperation} and monitoring systemic risks. The BSP has an early warning system to aid identification of weak banks and a measure of bank distress to assess whether a bank poses a systemic threat. It also has a Financial Stability Report (FSR) Committee to analyze emerging risks, vulnerabilities, and threats to financial stability. The BSP started producing an annual FSR in 2008 and plans to publish reports in the near future. In addition, the Financial Sector Forum (FSF), which meets at least bi-monthly, ensures information exchange and harmonization of policies to mitigate regulatory arbitrage. These functions are set out in MOUs between the FSF agencies.

\section{The FSF could consider further strengthened its capabilities by contingency} planning and forging closer links with the Department of Finance. Developing formal crisis contingency plans, including key data requirements, contact lists, and a public communication strategy in the event of a crisis would strengthen the FSF's financial stability function. And while there is informal communication with the Department of Finance, the

\footnotetext{
${ }^{20}$ Government securities, bank-owned real estate, foreign currency deposits at the BSP, mortgage credits with less than 360 days remaining maturity, and AAA commercial paper. Different haircuts apply to these forms of collateral, ranging from 20 to 75 percent.

${ }^{21}$ For example, the U.S. Federal Reserve limits this to one week.

${ }^{22}$ Currently, the BSP may grant uncollateralized loans for up to 7 days in times of need.
} 
28. Forum could establish more formal links, given the need for strong political support and timely responses in the event of a systemic crisis. ${ }^{23}$

\section{FinAnCial Sector OVERSight}

\section{A. Banking}

\section{Major progress has been made since the 2002 FSAP in strengthening the legal and regulatory framework and improving supervisory practices.}

- $\quad$ A legal framework for special purpose vehicles made possible a major reduction of banks' nonperforming assets following the crisis of the late 1990s. A new AML Act, introduced in 2003, is broadly in line with FATF recommendations. And the revised PDIC charter strengthened powers to examine banks.

- $\quad$ Supervisory coordination has also improved, addressing a key concern of the initial FSAP, with the creation of the Financial Sector Forum (FSF) and signing of memoranda of agreements (MOA) on information sharing. Furthermore, the BSP now has formal information-sharing agreements with five foreign supervisors.

- $\quad$ Capital adequacy, risk management, and corporate governance rules and guidance have been updated. The BSP has implemented Basel II (standardized approach for credit risk, basic indicator approach and standardized approach for operational risk, standardized and internal models for market risk, and Pillar 3 requirements), and important guidance on risk management functions. Furthermore, compliance and auditing rules were enhanced with the mandatory establishment of audit, corporate governance, and risk management committees.

- $\quad$ Supervision has advanced significantly, in line with initial FSAP recommendations. Market and liquidity risk supervision has been strengthened with new prudential reports and the use of specialized teams within on-site examinations. Credit and concentration risks supervision has also improved with enhanced guidance on large exposures and lending to related parties. ${ }^{24}$ The Manual of Regulations was updated, and manuals for supervisory procedures now emphasize risk assessment.

Additionally, supervisory functions have been strengthened with the creation of a

\footnotetext{
${ }^{23}$ International practice varies depending on country circumstances, and there is no established best practice regarding the form and content of institutional cooperation arrangements. Some ASEAN countries have councils (Indonesia), while others MOUs (Cambodia). Written agreements are also used in Hong Kong, the UK, and the European Monetary Union.

${ }^{24}$ Circular 423/2004 establishes lending ceilings for directors, officers, stockholders and related interests (DOSRI).
} 
- dedicated AML unit, intensive training, and extensive use of off-site tools. The improvement was recognized by banking industry representatives.

30. However, there are still some shortcomings.

- Inconsistencies exist between the regulatory guidance on related lending (DORSI) and the single borrower limit in the General Banking Law (GBL), which uses a narrower definition of connected counterparties.

- Many prudential limits, sanctions, and fines are detailed in legislation, hampering the BSP's ability to adjust these in a timely manner when necessary, and preventing full compliance with international standards.

- Deficiencies in the legal power of and legal protection for supervisors hamper compliance with BCP principles on autonomy, but also the overall enforcement of the principles related to capital, ownership, consolidated supervision, corrective and remedial powers, as well as the ability to conduct risk-based supervision.

31. Given that most of these shortcomings are embedded in legislation, the authorities have followed a pragmatic approach, attempting to address them through administrative means. The creation of the Directors' and Officers' Liability Insurance ${ }^{25}$ in 2005 enhanced the protection of supervisors acting in good faith. Also, the BSP has improved guidance on due process for supervisors. While effective, however, these fixes do not fully address the constraints embedded in the law or legal process. In particular,

- $\quad$ The law still considers supervisors civilly liable if they have not applied "extraordinary diligence." This makes it risky for supervisors to go beyond compliance checking and to take timely remedial measures and results in long and cumbersome procedures (notably in the case of the PCA discussed above).

- While recent Supreme Court rulings reinforced BSP's intervention authority, ${ }^{26}$ another decision requires "prior notice" of AML inquiries, weakening investigative powers.

32. The BSP is well aware that these legal shortcomings unduly limit its authority, and has proposed amendments to the New Central Banking Act (NCBA). These include deleting the "extraordinary diligence" requirement; granting the BSP authority to request

\footnotetext{
${ }^{25}$ A self insurance fund that complements the insurance provided by the GSIS and covers "all cases or suitspast and present — filed against a central bank official in relation to his/her work."

${ }^{26}$ In settling a long-standing case against the BSP, the Supreme Court ruled that the BSP's actions could not be restrained or set aside by lower courts unless it acted with "grave abuse of discretion".
} 
additional information, making it possible to supervise conglomerates "up the chain"; broadening the definition of control; expanding examination authority to align the text more with risk-based supervision needs; establishing that lower courts cannot issue temporary restraining orders against BSP actions; and granting it authority to establish different capital ratios for individual financial institutions.

\section{The proposed amendments would go a long way to address the remaining} shortcomings and should be enacted as soon as possible, but with additional legal and regulatory changes to:

- $\quad$ relegate the prudential limit levels and amount of fines to regulations;

- $\quad$ increase the discretion of the BSP to require additional capital and impose other limits relative to the risk profile of a bank, in line with the current capital adequacy regulation: ${ }^{27}$

- $\quad$ align the definition of connected counterparties in the law with the DOSRI regulations already in force;

- $\quad$ ensure the single borrower limits and large exposures are calculated on solo and consolidated basis, including all on- and off-balance sheet exposures, as a function of the same definition of capital (a recommendation of the 2002 FSAP); and

- $\quad$ set a regulatory aggregate limit for the sum of large exposures considering concentration risks in the system and international best practice.

\section{B. Capital Market}

34. Since 2002, authorities have made progress in implementing initial FSAP recommendations, but face continuing legal and resource constraints. The initial IOSCO assessment concluded that improved compliance hinged on continued efforts of the SEC and Philippine Stock Exchange (PSE) to enhance enforcement. Since then, efforts to improve compliance have been made, but legal authority and resource limitations stymie progress.

\section{Improvements are required in three key areas:}

- $\quad$ SEC regular on-site examinations. The SEC does not conduct routine on-site examinations of regulated entities. Due to resource limitations, on-site examinations are performed only "for cause". All regulated entities should be subject to regular onsite examinations. One focus of these should be on the calculation of net asset value

\footnotetext{
${ }^{27}$ Circular 639 makes it clear that capital should cover all the "risks that are inherent in their activities and material to their bank", and "consistent with their risk profile, operating environment, and business plans".
} 
by mutual funds, and broker-dealer compliance with risk-based capital adequacy standards. The SEC should also develop its own market surveillance program to monitor trading on the PSE, the Philippine Dealing and Exchange Corporation (PDEX), and on the two registered alternative trading systems when operations begin. The Revised Investment Company Act must be enacted (identified as a priority in the initial FSAP).

- $\quad$ SEC and PSE enforcement powers. Legal constraints, e.g., the bank secrecy law, make it difficult to investigate major misconduct. And while the SEC has referred 27 investigations to the Justice Department in the past three years, no criminal convictions have resulted (the most recent conviction concerned a crime that happened a decade ago). Addressing these shortcomings requires exempting the SEC from the bank secrecy act when investigating violations; granting the SEC authority to bring civil enforcement actions and issue disgorgement orders that require violators to repay investor losses; and increasing the maximum fines that the SEC may impose in a cease-and-desist order.

- $\quad$ The self-regulatory structure. The PSE should comply with the legal requirements on diversified ownership that were made a condition of its demutualization. Furthermore, an effective self-regulatory program must have adequate resources and operate independently from the business side of the PSE. The PSE has taken an important interim step to address this by creating the Market Integrity Board, but the plan developed to create a legally independent, single, autonomous self-regulatory entity that oversees both the PSE and the Philippine Dealing and Exchange (PDEX) should be implemented.

36. Addressing these priorities requires rationalizing the SEC's mandate, ensuring it has sufficient resources, and providing its staff with adequate legal protection.

- $\quad$ The SEC has a number of functions not common to a capital market regulator (e.g., company registration, and the government-sponsored credit bureau).

- The SEC has approximately 400 staff, about the same as in 2000 , when staff was reduced almost by half following the decision to automate the labor-intensive company registration program. However, the automation of the company registration and reporting process has not been completed (and almost 20 percent of the staff of the SEC is still assigned to this task).

- Due to lack of resources, the SEC lacks an adequate market surveillance program for public listed companies, and cannot hire sufficient staff to conduct examinations of mutual funds and market intermediaries.

- $\quad$ The SEC has not been able to pay salaries commensurate with the BSP, as required by law. 
- $\quad$ SEC commissioners and staff may not be indemnified for costs and expenses if they fail to exercise "extraordinary diligence"-a term that is not defined in law and creates legal uncertainty for SEC staff, as it does for BSP staff.

\section{Insurance}

37. The Insurance Commission (IC) lacks sufficient independence. A government agency under the Department of Finance, the IC is funded by annual budget allocations. Staff is employed under the same rules as other public servants and at rates of remuneration well below the industry. Partly as a result, staffing has declined to levels that hamper effective supervision. As elsewhere, staff is not provided with adequate legal protection.

38. Supervision is not sufficiently risk-based. The emphasis remains on checking compliance with rules for product approval, investments, capital, and net worth, and, more recently, governance obligations. Some progress has been made, notably with the development of risk-based capital (RBC) and the variable and proportionate regulations for Mutual Benefits Associations (MBAs), particularly microinsurance MBAs. However, key components of a risk-based supervisory regime are not in place.

\section{To support a risk-based approach and improve observance of IAIS standards,} the Insurance Code must be updated. The Insurance Code (1978) and regulations and circulars are out of date and fall short of international best practice. The Commission and the industry have prepared amendments to the code. However, these amendments are insufficient; if passed, they would serve to reinforce the compliance-based regime and fail to meet IAIS standards. These amendments need to be supplemented by provisions that support a risk-based regime:

- a broader set of discretionary intervention tools that can be initiated in a risk-based context; ${ }^{28}$ and

- $\quad$ relegation of procedural items requiring Insurance Commission approval (e.g., investments by individual companies or new retail products) from the law to Commission circulars, to allow flexibility to liberalize these over time.

40. The risk-based capital (RBC) formula could be improved and the minimum liability rules brought in line with international standards. Current yields for new investments are below rates factored into product prices and the liability valuation requirements for conventional insurance. The minimum liability rules should be strengthened and the valuation approach harmonized with International Accounting Standards. The RBC

\footnotetext{
${ }^{28}$ Such as powers to issue cease-and-desist orders, powers to enforce fitness and propriety broadly defined and applicable to both directors and officers (currently granted only to executive officers), and the ability to require a business plan for a period specified by the Commissioner rather than in the law.
} 
41. formula should have parameters more consistent with Philippine risk profiles, a threshold for intervention set at least at the level of the full RBC requirements, and incorporate more of the investment rules (reducing stand alone rules).

42. The Commission also needs adequate resources to ensure the credibility of oversight and accelerate the pace of the required changes. This is particularly important given the impending shift of pre-needs company supervision to the Insurance Commission.

\section{AML-CFT ${ }^{29}$}

43. The authorities have taken significant steps to address the concerns highlighted in the $2003 \mathrm{AML} / \mathrm{CFT}$ assessment, but challenges remain. The main remaining shortcomings in the legal AML/CFT framework are the absence of several offenses from the predicate crimes list, the failure to make terrorism financing a stand-alone offense, and the deficient implementation of UN Security Council resolutions. Furthermore, financial institutions are the only entities subject to full AML/CFT provisions, procedures for access to bank records by law enforcement agencies are cumbersome, and the involvement of these agencies in the financial component of predicate investigations is limited. Moreover, the limited integrity of the national government ID system undermines customer identity verification efforts. Lastly, there is a mismatch between agencies resources and the tasks assigned to them by law.

\section{DEVELOPMENTAL ISSUES IN NONBANK SECTORS ${ }^{30}$}

\section{A. Capital Markets}

44. Capital market development may be best served by measures to improve market functioning and integrity. There is no obvious, single reason why the Philippines lags its peers in this area. Many of the reasons reflect long-standing characteristics of the economylow national savings rates, high government borrowing, limited need for investment capital (most growth being service sector-based), and the dominance of family-run or closely-held conglomerates. Policy action may impact these only in the very long term. Nonetheless, some measures could improve market functioning and indirectly spur development:

- $\quad$ Rationalize and reduce transaction-based taxes, notably the exemption for banks on Final Withholding Tax, calculation of transactions taxes on gross rather than net basis, and the Depository Stamp Tax.

\footnotetext{
${ }^{29}$ A World Bank mission conducted an AML-CFT assessment of the Philippines in September 2008. The detailed assessment report was adopted by the Asia-Pacific Group in July 2009 (available on their web site). A ROSC is being prepared and will be circulated to the Board when completed.

${ }^{30}$ This section focuses on nonbank issues that are macro-relevant (e.g., growth enhancing or risk diversification measures).
} 
- $\quad$ Reduce the time and expense of debt offerings. Information contained in required filings largely duplicates that included in annual and quarterly reports. The SEC could adopt an expedited process and a no-review policy for some companies or facilitate the use of shelf registration statements (which are rarely used because of the substantial filing fees that must be paid upon filing).

- $\quad$ Reduce the time and expense of supplemental mutual fund offerings, for instance through a short-form registration statement and an expedited review process for increases in authorized shares required of open mutual funds to accommodate inflows.

- $\quad$ Introduce regulatory changes to assist mutual fund investors. The SEC should amend its rules to permit licensed professionals to sell more than one company's mutual funds and permit mutual fund companies to contract with banks, brokers, and other licensed professionals to sell their products.

\section{B. Housing Finance}

\section{Several government housing finance entities have unclear or overlapping} mandates, are poorly managed, and have low-quality portfolios. They have limited expertise in credit underwriting, servicing, and management of credit risk, as reflected in extraordinarily high NPL ratios. Many are mandated to distribute the same subsidized credit product ( 6 percent fixed rate, 30 years). These lenders create moral hazard, do not provide social housing effectively as their cash flows are crippled by the poor performance of their portfolio, and give rise to fiscal contingent liabilities.

46. Comprehensive reform is urgently needed to make the system more effective, targeted, and transparent and re-think the role of public institutions in this market should be revised accordingly. There is urgent need to reform, in particular, the Home Guarantee Corporation, which does not meet prudential actuarial principles and generates sizeable fiscal contingent liabilities; the National Housing Mortgage Finance Corporation, which does not seem to have a clear business case; and Pag-Ibig, the largest housing lender, which has elevated debt collection problems and NPLs, while representing a source of unfair competition for banks.

\section{Insurance}

47. Access has improved, but some policies distort the market and stunt growth. Mutual benefit associations focused on micro-insurance have expanded - assisted by regulatory capital concessions and tax incentives - while the conditions identified by the Microinsurance Network good practice guidelines and IAIS are present. However, once 2006 capital requirements are fully implemented in 2011, minimum capital levels will be among the highest in the world, especially for foreign-owned companies. Furthermore, there are restrictions on expanding the range of providers, as well as on micro-insurers introducing 
non-life products. Moreover, premium-based taxes and the tax on the savings element vary between types of providers. Lastly, the state-owned Government Services Insurance System (GSIS) which has a monopoly on insuring "government risks," while also giving loans to non-members, competes directly with the private market on insurance for government employees and by requiring borrowers to take out life insurance from the GSIS. 


\section{Appendix I. A Contingent Claims Analysis of Corporate Vulnerabilities}

\section{The contingent claims analysis (CCA) utilizes both balance sheet information} and stock prices of corporations to obtain forward-looking information about the risk of default ${ }^{31}$ Under this approach, the risk of default is related to the probability that the value of a firm's assets will fall below the value of its liabilities. This, in turn, is determined by two factors: (i) firm leverage (debt relative to the market value of equity) and (ii) the uncertainty about the value of a firm's assets. These two factors depend on the vagaries of stock markets. For example, a decline in stock prices raises leverage and a spike in stock price volatility increases the uncertainty about asset values. In both cases in this example, the probability of default increases. Based on this, expected default probabilities one year ahead can be calculated using the contingent claims framework. The analysis in this Appendix uses data from Moody's KMV - Credit Edge, which cover a significant share of the listed companies in the Philippines in terms of market capitalization.

\section{The CCA also allows for the calculation of expected losses from corporate} defaults. These losses refer to the present value of expected losses due to default, estimated using the market information on firm's equity, assets, and debt. It should be kept in mind, however, that these estimates are not comprehensive measures of corporate losses. Instead, they represent the losses that creditors, bondholders, and banks would incur after the equity of defaulting companies' shareholders has been wiped out. Therefore, these estimates are best suited for international comparisons, or to derive the effect on a certain class of creditors, namely the banking system.

50. The estimated expected losses from corporate defaults are broadly in line with levels seen for regional peers (Figure 1). According to the CCA, the Philippine corporate creditors can be expected to incur losses equivalent to around $3 \frac{1}{2}$ percent of corporate liabilities over the next year. This is broadly in line with the average level for ASEAN countries, but higher than industrial Asia, partly reflecting historically lower recovery rates for creditors in ASEAN countries. However, compared to GDP, the potential corporate losses are relatively small, only around 1 percent of GDP for the Philippines, compared to $1 \frac{1}{4}$ percent of GDP for Asia as a whole. This also means that the potential knock-on effect on Philippine banks can be expected to be manageable, especially given the low credit-to-GDP ratio in the Philippines.

\footnotetext{
${ }^{31}$ For further details, see Gapen, Gray, Lim, and Xiao (2004), "The Contingent Claims Approach to Corporate Vulnerability Analysis: Estimating Default Risk and Economy-wide Risk Transfer," IMF Working Paper 04/121. See also Jain-Chandra, N'Diaye, and Oura (2009), “How Vulnerable is Corporate Asia?" Regional Economic Outlook, Asia and Pacific, May 2009, International Monetary Fund.
} 
Figure 1. Corporate Vulnerabilities

According to contingent claims analysis, ASEAN, including Philippine, corporations face the largest losses in Asia,

Asia: Non-Financial Corporate Sector - Annual Average Expected Losses One Year Ahead /1

(In percent of corporate sector liabilities)

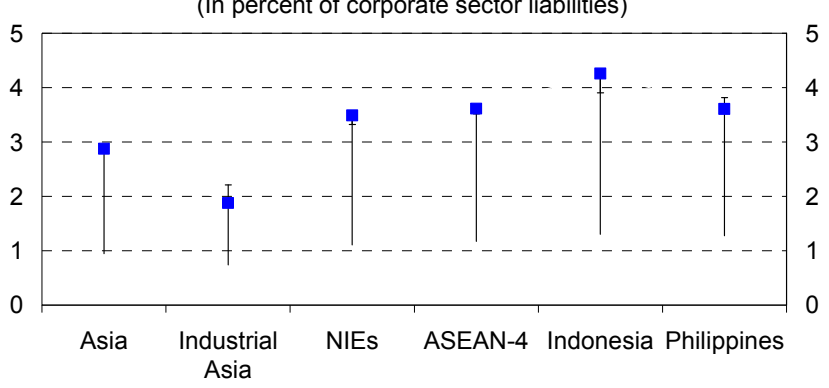

Source: Moody's KMV - Credit Edge; and IMF staff estimates.

$1 /$ Dots represent point estimates. Confidence intervals assume 80 percent and 40 percent recovery rate in case of default. ....although the losses are small relative to GDP, partly due to the less developed financial markets in these countries.

Asia: Non-Financial Corporate Sector - Annual Average Expected Losses One Year Ahead $/ 1$

(In percent of GDP)

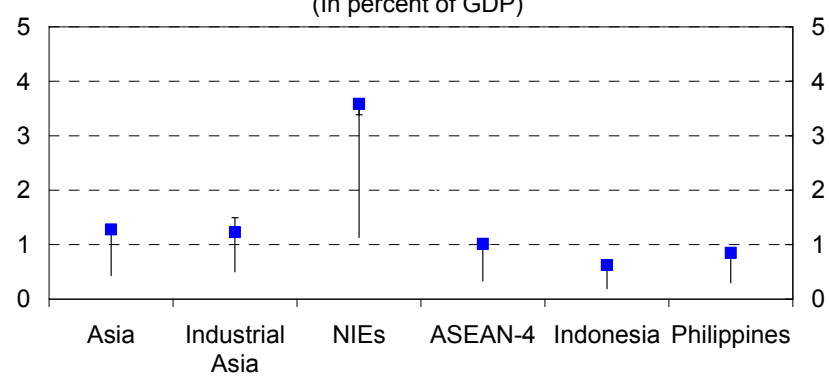

Sources: Moody's KMV - Credit Edge; and IMF staff estimates.

$1 /$ Dots represent point estimates. Confidence intervals assume 80 percent and 40 percent recovery rate in case of default. 


\section{Appendix II. Bank Derivatives Activities in the Philippines}

51. The notional amount of stand-alone derivatives held by Philippine banks wason average between February 2008 and August 2009—about P2.3 trillion ( $\$ 50$ billion). ${ }^{32}$ Embedded derivatives (e.g. structured notes) represented about P13 billion ( $\$ 275$ million).

\section{Foreign exchange derivatives are the most frequently stand-alone traded} instruments, with foreign exchange forwards and swaps together constituting two-thirds of all derivative contracts and foreign exchange swaps representing about half of the derivatives markets. The majority of derivative transactions are short-term (less than one year).

Stand-alone Bank Derivatives Transactions (Market Share by Notional Amount)

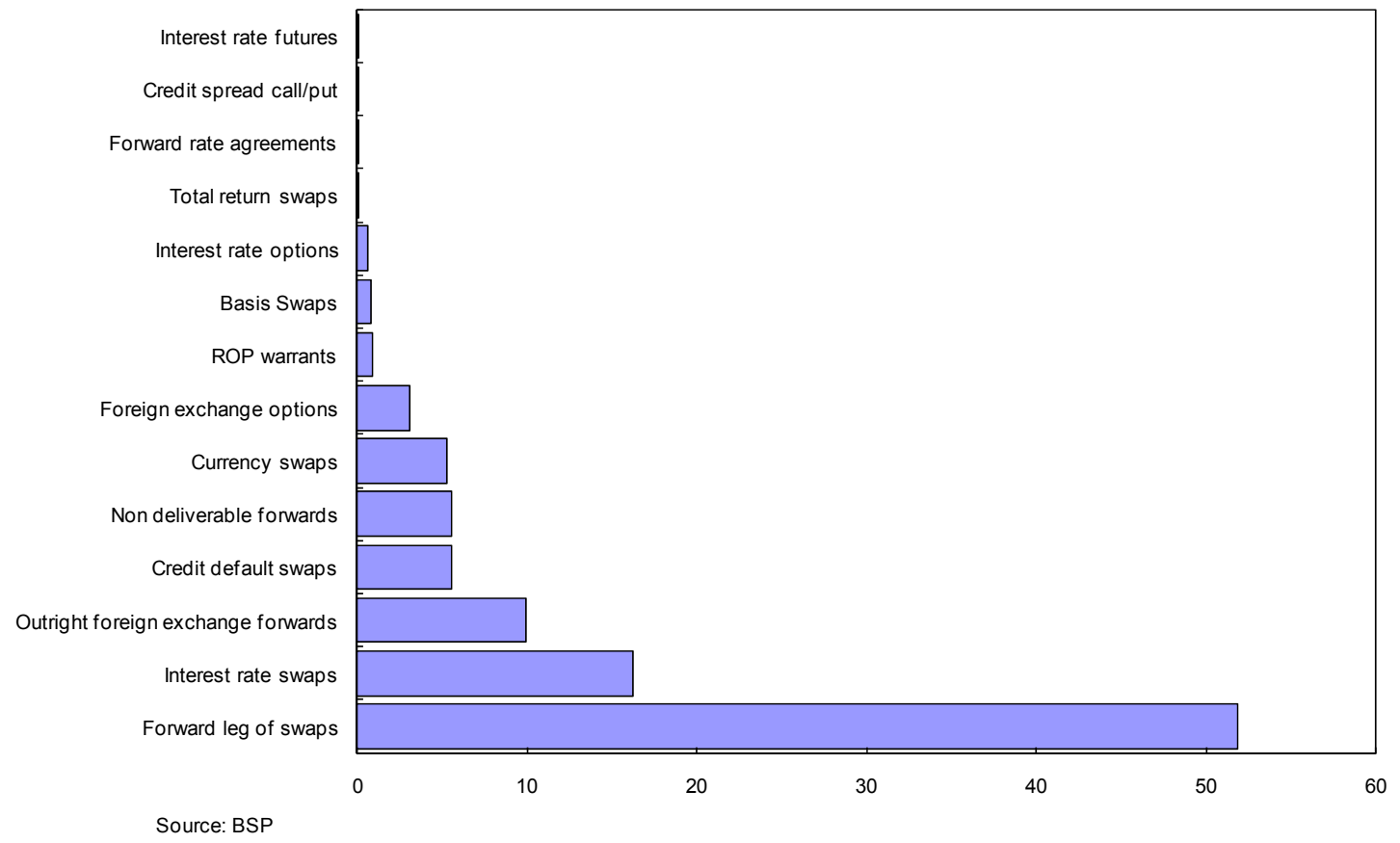

53. The most popular structured notes in the Philippines are range-accrual notes, plain vanilla credit-linked notes, and leveraged credit-linked notes. The fact that reference assets on which banks sell protection are usually Philippine government bondswhose return/risk profile is well known by the local banks - speaks of the conservative approach that banks took to structured products. However, this approach could create higher systemic risk in the event of fiscal problems, since it would compound bank losses from these products. Moreover, for the seller of the notes, these structures imply a wrong way exposure (i.e., protection is sold on a risk to which the seller is also exposed).

\footnotetext{
${ }^{32}$ They represent about 50 percent of banking assets, which low by international standards. In the U.S., for example, the ratio of notional value of derivatives contracts held by banks is 17 times total bank assets.
} 
54. Foreign banks lead the local derivatives activities in the Philippines due to their expertise and also as a result of regulations that prescribe different types of licenses to participate in this market. Licenses depend on the complexity of the products, their term, and on whether the banks take positions for them or act on behalf of their clients. No domestic bank has the broadest type of license (Type 1 or expanded dealer). They either have Type 2 (limited dealer) or Type 3 (end-user) authority. Most domestic bank activities are end-users (proprietary trading or hedging exposures) and their counterparties are foreign banks with a presence in the Philippines or off-shore international banks.

55. Derivatives expose banks to market and counterparty risks. These can be measured by current exposures (i.e., the current value of the contract) and by potential exposures given specific scenarios, usually measured by value-at-risk methodologies. ${ }^{33}$ Counterparty risk to foreign counterparties through credit-linked notes (CLN) was significantly reduced after the global crisis.

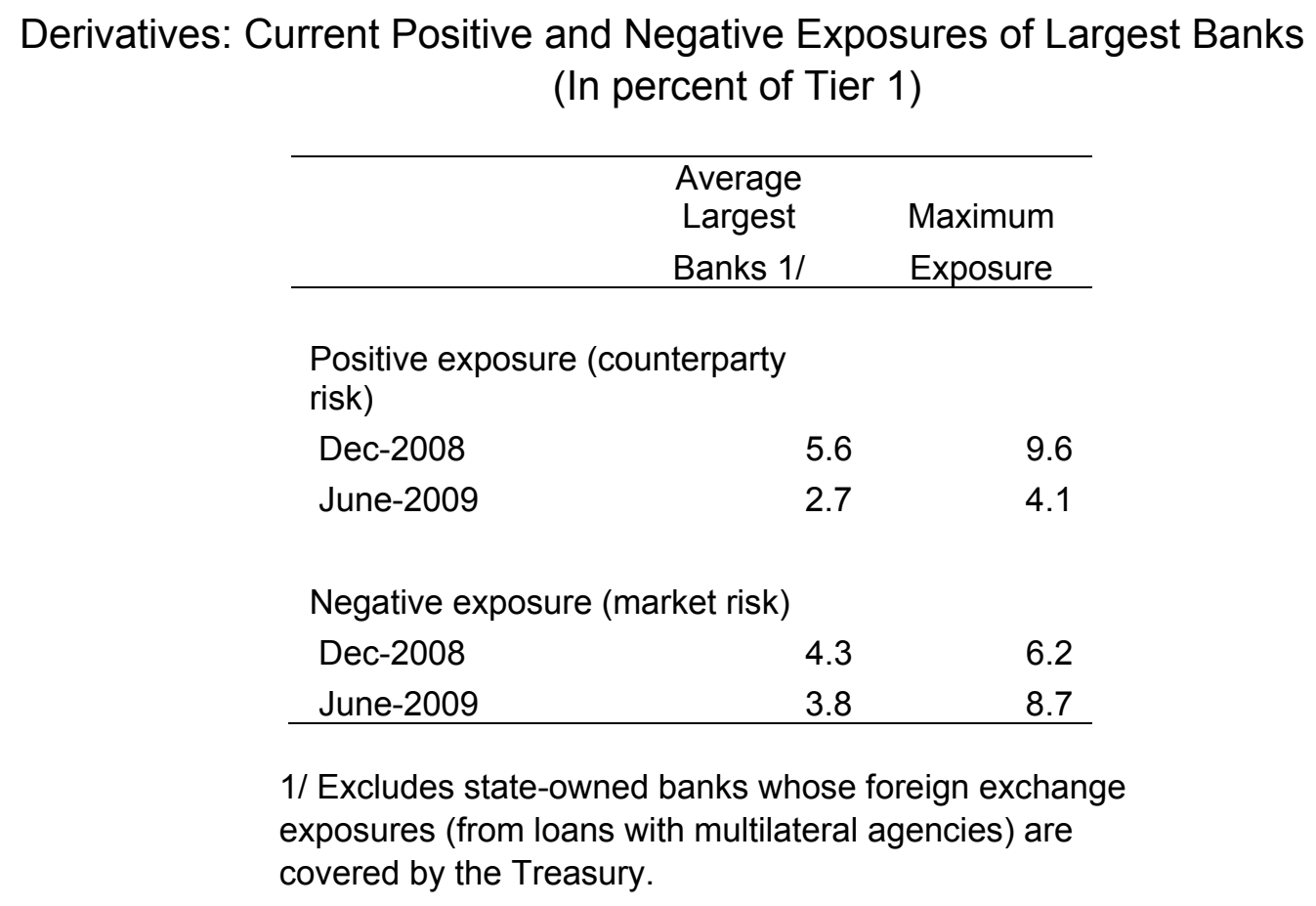

\footnotetext{
${ }^{33}$ As of October 2009, the overall Value at Risk (included from derivatives) reported by the largest banks, following the Basel rules for the measurement of market risk, was less than 0.5 percent of Tier 1.
} 


\section{Appendix III. Stress Testing Methodology}

This appendix describes the macroeconomic risk model estimated by staff for the stress tests related to credit risk.

56. Following a large body of theoretical and empirical literature, credit risk was modeled as a function of a set of macroeconomic variables. This captures the systemic component of credit risk and assumes that all specific risk (e.g. for exposures to specific sectors or borrowers) is diversified away. Specifically, the systemic component is responsible for tail risk (to the extent that many or all borrowers are affected by a common set of factors).

57. Credit risk is represented by the ratio of NPL which is modeled by the logistic functional form in order to better capture tail risk and ensure that all forecasts will lie in the [0-1] interval.

$$
N P L_{t}=\frac{1}{1+\exp \left(y_{t}\right)}
$$

where the variable $y_{t}$ can be interpreted as an index representing the state of the economy. A higher value of $y$ is associated with an improvement in the credit quality of bank portfolios. The logistic functional form is also convenient in that $\mathrm{y}$ is given by the logit transformation:

$$
L\left(N P L_{t}\right)=\ln \frac{\left(1-N P L_{t}\right)}{N P L_{t}}=y_{t}
$$

The logit transformation is then assumed to be a function of exogenous macroeconomic factors and a surprise factor represented by an error term, i.e.:

$$
y_{t}=\beta_{o}+\beta_{1} X_{1, t}+\beta_{2} X_{2, t}+\ldots \beta_{n} X_{n, t}+e_{t}
$$

58. Equation (3) was estimated for the Philippines for the period 2001:Q1-2008:Q4. Data for NPL corresponds to the time series provided by the authorities, corresponding to universal and commercial banks. This series was assessed by the authorities as the best available measure of NPL for Philippines banks with a consistent definition over the sample period. Dickey-Fuller tests suggest that for the Philippines, the logit transformation has a unit root. $^{34}$ In order to address this statistical fact, the regressions were estimated in first differences.

\footnotetext{
34 This finding is infrequent but not unique to Philippine data. The null hypothesis in all tests is that the logit transformation of NPL has a unit root. For different specifications (drift and trend), the t-statistics value is greater than the critical values at conventional confidence levels. Therefore the null cannot be rejected.
} 
59. The following macroeconomic variables were used as regressors: real GDP, remittances from Philippine workers abroad, a representative interest rate (the five-year bond yield on Philippine government bond) and the real effective exchange rate. Because of the high proportion of corporate loans in banks' portfolios, the predictive value of the aggregate corporate leverage ratio was also tested, although not incorporated in the final regression. Corporate leverage was obtained from Moody's KMV and defined as the ratio of (balance sheet) liabilities to market value of assets. This is a measure of leverage for all Philippine corporates (and not just bank clients). These variables should capture the impact of macroeconomic variables on both household and corporate clients.

60. Based on data availability, one regression was estimated for the total Philippine banking system. Available NPL time series by macroeconomic sectors are too short (a few quarters) to allow estimates of sectoral NPLs. Individual bank NPL time series were not available to staff. Therefore, once the level of NPLs is estimated conditional on different stress scenarios, the new aggregate NPLs have to be allocated to banks using a rule (e.g., in proportion to each bank's NPL) in order to assess the impact on individual bank capital. While this is a limitation, it also reflects the fact that systemic risk is rooted in macroeconomic factors that make diversification difficult. Model estimates are presented below.

- All variables have the expected signs. GDP growth has a positive impact on the quality of bank portfolios. The impact takes five quarters to materialize in lower NPLs. The model implies that one percentage point decrease in GDP growth would translate in 0.5 percentage point increase in NPLs. Remittances growth also has a positive impact on credit quality with the effect becoming apparent after three quarters. The independent impact of remittances on NPL is limited (to a large extent because remittances have an indirect impact through GDP).

- Bank portfolios are affected by a real depreciation of the real effective exchange rate and the impact appears to materialize quite soon. One possible channel for this result is a balance sheet effect on corporates with unhedged exposures in foreign currency.

- Higher interest rates have a negative impact on the quality of bank portfolios, although this does not appear significant

- The regression explains 67 percent of NPL variation.

- Corporate leverage has limited explanatory power, and this power disappears once other macroeconomic variables are included (not shown). 


\section{Table 1. Model Estimates}

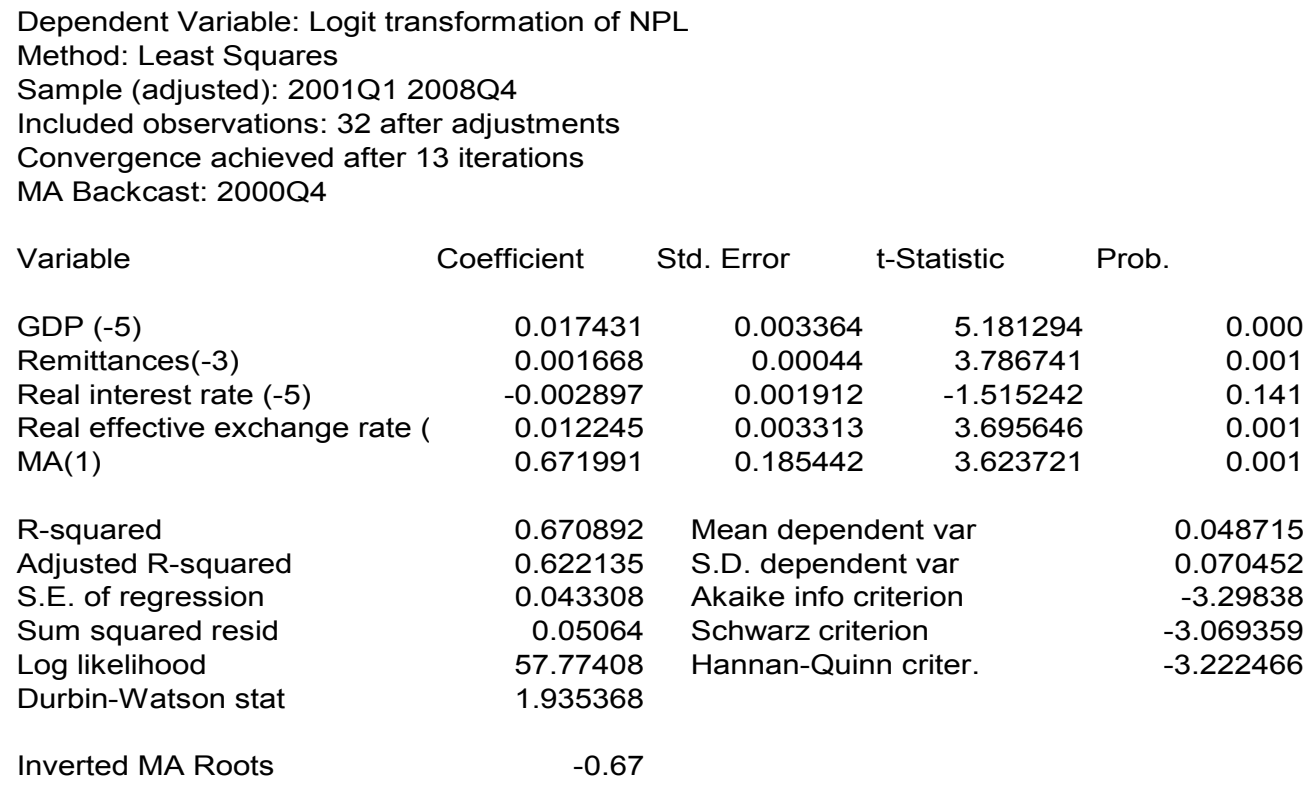

Model was estimated in first differences

\section{The stress scenarios}

61. Once the model was calibrated, it was used to forecast NPLs under four stress scenarios:

- A remittance shock characterized by a drop of 12 percent.

- An export shock triggered by a 50 percent decline in export values.

- A financial shock triggered by an increase in sovereign spreads of about 250 basis points.

- A shock combining all three shocks above.

\section{The rationale for these shocks are as follows:}

- The remittance and export shocks highlight the dependence of the Philippine economy on external factors. Although both shocks would impact GDP - and, indirectly, borrowers' default probabilities - the remittances shock would also have a direct impact on the default probabilities of Philippine households that use remittances to repay debt. Similarly, the export shock would have a direct impact on corporate defaults.

- The financial shock replicates some of the initial characteristics of the recent global financial crisis, in particular high interest rates, global illiquidity and a current account deficit that requires currency depreciation. These factors would feed into credit quality 
through higher interest rates on loans and potentially higher burden on debt denominated in foreign currency.

- Finally, a fourth scenario combines the remittances, export, and financial shocks into one. This scenario is more akin to the global recession that followed the recent global financial crisis.

63. The shocks were calibrated using the Philippines' historical information. The financial shock is triggered by an increase in sovereign spreads of about 250 basis points. The export shock is triggered by a 50 percent decline in exports value. The policy response is a depreciation of about 28 percent (about 3 standard deviations of changes in the real effective exchange rate for the period used for the model estimates). The remittance shock is represented by a 12 percent drop in their value. The worst decline in remittances during the period 1994-2008 was 22 percent in 1999. However, during the last ten years, the Philippines off-shore workers have spread to a more diversified geographical base and a more diversified range of professions, all of which resulted in an average annual remittance growth of about 13 percent since 2000 . Therefore, a 12 percent decline in a single year in the value of remittances would be an extreme outcome. The stress tests risk horizon is two years. All scenarios are characterized by a gradual return to normal conditions by the end of the second year.

Table 2. Philippines: Stress Scenarios for Stress Testing

\begin{tabular}{|c|c|c|c|c|c|c|c|c|}
\hline & \multicolumn{2}{|c|}{ Remittance shock } & \multicolumn{2}{|c|}{ Financial shock } & \multicolumn{2}{|c|}{ Export shock } & \multicolumn{2}{|c|}{ Combined shocks } \\
\hline & 2009 & 2010 & 2009 & 2010 & 2009 & 2010 & 2009 & 2010 \\
\hline Nominal GDP (percent change) & 0.9 & 5.7 & 1.9 & 6.4 & -1.5 & 6.3 & -2.0 & 6.3 \\
\hline Real GDP (percent change) & -2.0 & 1.3 & -1.5 & 1.8 & -4.0 & 1.7 & -6.0 & 2.0 \\
\hline LT interest rate (5-year TB) & 7.0 & 6.6 & 8.5 & 7.6 & 7.5 & 7.0 & 8.5 & 7.3 \\
\hline CPI (average percent change) & 4.2 & 4.3 & 5.2 & 4.7 & 6.2 & 4.3 & 7.2 & 4.3 \\
\hline Remittances (percent change) & -12.0 & 2.3 & -4.0 & 2.3 & -4.0 & 2.3 & -12.0 & 2.3 \\
\hline Exchange rate (Peso/USD) & 55.2 & 53.1 & 58.0 & 62.2 & 65.7 & 65.7 & 77.2 & 73.7 \\
\hline REER (percent change) & -15.7 & 7.9 & -19.0 & -2.9 & -27.8 & 3.8 & -38.0 & 8.7 \\
\hline \multicolumn{9}{|l|}{ Assumptions: } \\
\hline CDS (5 year) & 4.5 & 3.5 & 5.5 & 4.0 & 5.0 & 4.0 & 6.0 & 4.0 \\
\hline LIBOR (6 month) & 1.2 & 1.4 & 1.2 & 1.4 & 1.2 & 1.4 & 1.2 & 1.4 \\
\hline RRP & 5.0 & 4.5 & 5.5 & 5.0 & 5.0 & 4.5 & 5.0 & 4.5 \\
\hline
\end{tabular}


Forecasting NPLs using the model and the stress scenarios

64. The table below summarizes the projected NPL under each scenario. Apart from the scenario that combines all shocks, the scenario with a larger impact is the one triggered by the export shock. NPL loans increase by 10,26, 49 and 78 percent in each scenario respectively

Table 3. Forecasted Non-Performing Loans under Stress Scenarios

\begin{tabular}{lcccc}
\hline & Remittance shock & Financial shock & Export shock & Combined shocks \\
\hline 2008Q4 & 3.5 & 3.5 & 3.5 & 3.5 \\
2009Q1 & 3.3 & 3.3 & 3.3 & 3.3 \\
2009Q2 & 3.9 & 3.7 & 4.3 & 4.8 \\
2009Q3 & 3.5 & 3.3 & 3.9 & 4.3 \\
2009Q4 & 3.5 & 3.3 & 3.9 & 4.4 \\
2010Q1 & 3.3 & 3.1 & 3.6 & 4 \\
$2010 \mathrm{Q} 2$ & 4.4 & 3.8 & 5.2 & 6.2 \\
$2010 \mathrm{Q} 3$ & 4.0 & 3.5 & 4.7 & 5.7 \\
$2010 \mathrm{Q} 4$ & 4.0 & 3.4 & 4.7 & 5.7 \\
\hline
\end{tabular}

\section{Translating forecast NPL into bank capital ratios}

65. The increase in the nonperforming loan ratio forecast derived from the IMF model was translated into individual bank capital ratios under each scenario. For each bank, NPL loans grew at the forecast growth for the system. In order to estimate the new capital ratio for each bank under each scenario, provisions were raised so as to keep the current coverage constant for each bank. In addition, risk-weighted assets were adjusted up by 150 percent of NPL (minus provisions), following the Basel rule. 